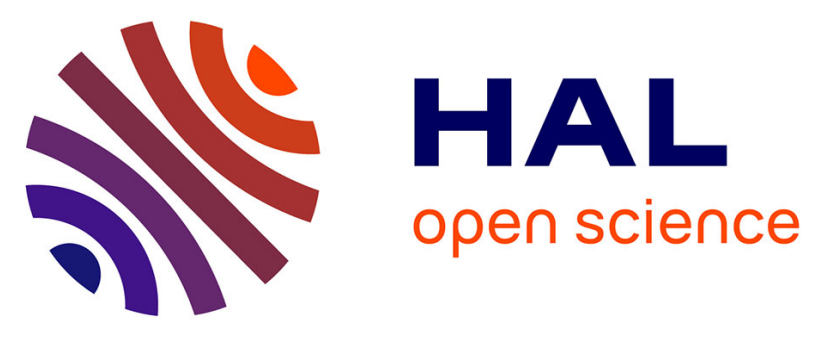

\title{
Basement - Cover decoupling and progressive exhumation of metamorphic sediments at hot rifted margin. Insights from the Northeastern Pyrenean analog
}

Camille Clerc, Yves Lagabrielle, Pierre Labaume, Jean-Claude Ringenbach, Alain Vauchez, Thierry Nalpas, Romain Bousquet, Jean-François Ballard, Abdeltif Lahfid, Serge Fourcade

\section{To cite this version:}

Camille Clerc, Yves Lagabrielle, Pierre Labaume, Jean-Claude Ringenbach, Alain Vauchez, et al.. Basement - Cover decoupling and progressive exhumation of metamorphic sediments at hot rifted margin. Insights from the Northeastern Pyrenean analog. Tectonophysics, 2016, 686, pp.82-97. 10.1016/j.tecto.2016.07.022 . insu-01355131

\section{HAL Id: insu-01355131 \\ https://hal-insu.archives-ouvertes.fr/insu-01355131}

Submitted on 23 Jan 2017

HAL is a multi-disciplinary open access archive for the deposit and dissemination of scientific research documents, whether they are published or not. The documents may come from teaching and research institutions in France or abroad, or from public or private research centers.
L'archive ouverte pluridisciplinaire HAL, est destinée au dépôt et à la diffusion de documents scientifiques de niveau recherche, publiés ou non, émanant des établissements d'enseignement et de recherche français ou étrangers, des laboratoires publics ou privés.

\section{(2)(1) $\$$}

Distributed under a Creative Commons Attribution - NonCommercial - NoDerivatives $\mid 4.0$ 
Basement - cover decoupling and progressive exhumation of metamorphic sediments at hot rifted margin. Insights from the Northeastern Pyrenean analog.

Clerc Camille, Lagabrielle Yves, Labaume Pierre, Ringenbach Jean-Claude, Vauchez Alain, Nalpas Thierry, Bousquet Romain, Ballard Jean-François, Lahfid Abdeltif, Fourcade Serge 


\section{Abstract}

We compile field data collected along the eastern part of the North Pyrenean Zone (NPZ) to point to a tectonic evolution under peculiar thermal conditions applying to the basin sediments in relation with the opening of the Cretaceous Pyrenean rift. Based on this compilation, we show that when thinning of the continental crust increased, isotherms moved closer to the surface with the result that the brittle-ductile transition propagated upward and reached sediments deposited at the early stage of the basin opening. During the continental breakup, the pre-rift Mesozoic cover was efficiently decoupled from the Paleozoic basement along the Triassic evaporite level and underwent drastic ductile thinning and boudinage. We suggest that the upper Albian and upper Cretaceous flysches acted as a blanket allowing temperature increase in the mobile pre-rift cover. Finally, we show that continuous spreading of the basin floor triggered the exhumation of the metamorphic, ductily sheared pre-rift cover, thus contributing to the progressive thinning of the sedimentary pile. In a second step, we investigate the detailed geological records of such a hot regime evolution along a referencesection of the eastern NPZ. We propose a balanced restoration from the Mouthoumet basement massif (north) to the Boucheville Albian basin (south). This section shows a north to south increase in the HT Pyrenean imprint from almost no metamorphic recrystallization to more than $600^{\circ} \mathrm{C}$ in the pre- and syn-rift sediments. From this reconstruction, we propose a scenario of tectonic thinning involving the exhumation of the pre-rift cover by the activation of various detachment surfaces at different levels in the sedimentary pile. In a third step, examination of the architecture of current distal passive margin domains provides confident comparison between the Pyrenean case and modern analogs. Finally, we propose a general evolutionary model for the pre-rift sequence of the Northeastern Pyrenean rifted margin. 
Keywords: Structural Geology; Passive margin; Pyrenees; HT metamorphism; extension; rifting 


\section{Introduction: The Cretaceous basins of the North Pyrenean Zone (NPZ), a case study of synchronous sedimentation and syn-metamorphic HT-LP deformation.}

Recent studies of continental passive margins collectively describe a great variety of processes accounting for the extreme thinning of the continental crust. Among all the parameters that may act during crustal stretching, the thermal state of the system and the temporal evolution of the heat distribution during thinning appear of major importance. An important issue is thus to better describe the thermal conditions of a variety of passive margins, including inverted passive margins in orogens where the most distal portions of the system is often well exposed. The Pyrenees are now known to expose remarkably wellpreserved sections representative of most of the domains constituting inverted mid-Cretaceous continental passive margins, from the external domains to the domain of exhumed mantle (refs). Moreover, a specific model of continental thinning and breakup under high thermal conditions has been recently proposed to account for a number of geological features of the North Pyrenean Zone (NPZ) (fig. 1; Clerc and Lagabrielle, 2014). This model applies to the internal part of the mid-Cretaceous Pyrenean rift and differs significantly from models of cold passive margins (i.e.: Type I model of Huismans et Beaumont 2011, 2014). It implies that during stretching, the thinned continental crust is extracted horizontally from its original location between the pre-rift sediments and the sub-continental mantle. When thinning increases, isotherms move closer to the surface so that the brittle-ductile transition propagates upward and reaches sediments deposited at the early stage of the basin opening. This model accounts for the early tectonic contact between exhumed mantle rocks and pre-rift sediments and for the ductile deformation of the pre-rift sediments under HT-LP conditions well observed along the Internal Metamorphic Zone (IMZ) of the NPZ. In the following, we shed light on two major geological features of the IMZ that can be summarized as follows: (1) synrift, Albian-to Turonian flysch sequences were deposited while the carbonate pre-rift 
sequences were ductily deformed in the deepest parts of the basins, and (2) all along the IMZ, the Mesozoic strata recorded a high-temperature metamorphic event dated from the Albian to Coniacian, indicating a long lasting thermal anomaly and continuous flysch sedimentation (e.g. Vacherat et al., 2014; Clerc et al., 2015). Such a synchronicity between flysch sedimentation and HT metamorphism at depth is not commonly described is the literature. This leads us to examine how tectonics, metamorphism and sedimentation may be active in a single basin during continental extension leading to mantle exhumation. This work outlines how geological investigations in inland analogs may help better understanding the poorly known architecture and lithology of distal continental margins.

\section{The NPZ as an analog of distal passive margins}

The Pyrenean belt is the result of the convergence between the Iberia and the Europa plates, which started during the late Cretaceous (late Santonian) and ended during the early Miocene. Geological and geophysical studies have shown that the belt forms an asymmetric doubleverging tectonic wedge above the north-dipping Iberian continental lithosphere (e.g. Choukroune and ECORS Team, 1989; Roure et al., 1989; Muñoz, 1992; Vergés et al., 1995; Teixell, 1998; Teixell et al., 2015). The Pyrenean convergence resulted in the inversion of the rifted domain that separated the Iberia and Europe continents from the late Aptian to the late Santonian. However, the paleogeographic reconstruction of the plate pattern remains a subject of major debate, with two end-member kinematic models describing the motion of Iberia with respect to Europe during rifting: (1) a scissor-type opening model for the Bay of Biscay (Srivastava et al. 2000, Rosenbaum et al., 2002; Sibuet et al., 2004), and (2) a left- lateral strikeslip opening model (Le Pichon et al., 1970; Choukroune and Mattauer, 1978, Olivet, 1996; Stampfli et al., 2002, Jammes et al., 2009; Handy et al., 2010). Due to such discrepancies between existing models, there is still a debate regarding the maximum width of the domain opened between the Iberia and the Europa plates and the timing and amount of strike-slip 
movement. The maximum basin width was proposed by Vissers and Meijer (2012), with 300 $\mathrm{km}$ of mantle-dominated ocean floor exhumed during the late Jurassic and early Cretaceous, then subducted during the inversion. On the other hand, the model of dominant strike-slip motion involves the opening of numerous narrow pull-apart basins (Choukroune and Mattauer, 1978). However, in the most recent models, there is a general agreement that the movement of Iberia relative to Europe was accommodated within a wide, diffuse plate boundary along which E-W trending transtensional basins opened (Jammes et al. 2009, 2010; Tugend et al., 2014). In this view, the Cretaceous rift system must be considered as integrating not only the inverted North Pyrenean basins, but also the Los Cameros, Organya, Arzacq, Parentis and the BasqueCantabrian basins, which correspond to a present-day width of $360 \mathrm{~km}$ extending up to circa $500 \mathrm{~km}$ when restored before the Pyrenean shortening.

The Paleozoic rocks forming the basement of the Meso-Cenozoic sediments involved in the Pyrenean belt are mainly exposed in the central part where they form the high elevation Axial Zone. The Axial Zone is bounded to the north by the $\sim$ EW-trending North Pyrenean Fault (NPF). North of this fault, the North Pyrenean Zone (NPZ) is a narrow belt of Mesozoic sediments and Paleozoic massifs running over $\sim 400 \mathrm{~km}$ all along the range (Bertrand 1940; Mattauer 1968; Mattauer and Henry 1974; fig. 2). The NPZ represents the main system of inverted sedimentary basins that opened between Iberia and Europa during the Cretaceous rifting.

Following a period of moderate extensional tectonic activity during the Jurassic and Neocomian, the main rifting episode occurred from the late Aptian to the early Cenomanian with the formation of rift basins filled by dark-colored, flysch-type sediments, referred to as the "Flysch Noir" (Black Flysch) or "Flysch Ardoisier" (Debroas 1976; Debroas 1978; Souquet et al. 1985; Debroas 1987; Debroas 1990). However, this basin frequently comprised a central basement high corresponding to the present-day North Pyrenean massifs (Debroas, 
1990). From the middle Cenomanian to the onset of compression in the late Santonian, the basin widened with flysch deposition overlapping the North Pyrenean massifs and the northern border of the Axial Zone. Although this period is sometimes considered as a "postrift" period (Jammes et al., 2010), the presence of conglomerates of various ages from the Cenomanian to Santonian along the North Pyrenean Fault and locally in the core of the NPZ (Montigny et al., 1986; Debroas, 1987; Debroas, 1990) attest to continuing tectonic activity. The precise tectonic context of this period remains poorly understood and, although a transpressional tectonic activity has been proposed (Debroas, 1990), the general kinematic context suggests a continuation of extensional tectonics.

The Mesozoic sediments exposed in the NPZ have experienced a regional HT-LP metamorphic event prior to the Pyrenean orogeny. Paleothermometric measurements reveal a zonation in three main domains at the scale of the whole NPZ (Ravier 1959; Bernus-Maury 1984; Golberg et Leyreloup 1990; Clerc et al. 2015). From west to east, these are (Fig. 2): (1) the western domain (Mauléon basin), which shows low grade metamorphism with temperatures generally lower than $350^{\circ} \mathrm{C}$ (Clerc et al., 2015); (2) the central domain (Ballongue, Barousse and Baronnies basins), displaying higher temperatures of 300 to $450^{\circ} \mathrm{C}$ (Goujou et al., 1988; Clerc et al, 2015), locally exceeding $550^{\circ} \mathrm{C}$ close to mantle exposures (Arguenos-Moncaup peridotite body); (3) the eastern domain, including the Aulus, Pays de Sault, Boucheville and Agly Cretaceous basins, which presents the highest grade of HT-LP metamorphism with peak temperatures around to $600^{\circ} \mathrm{C}$ and above (Golberg and Leyreloup, 1990; Clerc et al., 2015). In addition to the east-west thermal zonation, a north-south thermal gradient is observed in this eastern domain. The highest temperatures are found in the southernmost basins (Boucheville and Aulus), whereas the northern basins (e.g.: Saint-Paulde-Fenouillet and Camarade) are characterized by a rapid decrease of the metamorphic imprint. 
A particular feature of the NPZ is the occurrence of several tens of subcontinental peridotites bodies a few meters to $3 \mathrm{~km}$ across, scattered within Mesozoic metasediments and associated with remnants of the Paleozoic basement. These peridotites are known to have reached crustal levels during the mid-Cretaceous (Golberg et al., 1986; Montigny et al. 1986; Bodinier et al. 1987; Fabriès et al. 1991; Fabriès et al., 1998). To account for the occurrence of mantle rocks in the NPZ, a recent model of mantle exhumation, which associates extreme continental thinning with tectonic fragmentation and sedimentary transport of ultramafic debris on the seafloor, has been proposed for the Lherz region (Lagabrielle and Bodinier, 2008; Clerc et al., 2012; 2013; Lagabrielle et al., 2015). In agreement with this model, other studies point to the fact that the mantle rocks were exhumed to upper crustal levels, but not always exposed to the seafloor (Jammes et al., 2009; 2010, Lagabrielle et al., 2010; Clerc et al., 2012; 2014; Masini et al., 2014; Tugend et al., 2014; Corre et al., 2015; de St Blanquat et al., 2015).

The compilation of chronological and geological data from the NPZ reveals a correlation during the mid- to late Cretaceous between the distribution of the highest paleotemperatures in the Mesozoic sedimentary cover and the loci of extreme crustal thinning attested by the association of Mesozoic sediments, subcontinental peridotites and limited alkaline magmatic activity (Golberg and Leyreloup, 1990; Clerc et al, 2015).

In order to integrate these geological features into a single and consistent model, a mechanism of crustal thinning involving boudinage of the continental crust and mantle exhumation has been proposed (Clerc and Lagabrielle, 2014). Here, we emphasize that this model is consistent with the peculiar geometry of the Cretaceous basins floor foreboded by Casteras (1933) and Ravier (1959), who pointed out to a smooth attenuation of the continental crust (Fig. 3). Pioneer works also revealed a major geological discontinuity referred to as the "preCenomanian unconformity” (Durand-Delga, 1964, 1965; Mattauer and Proust, 1964; Casteras, 1965), observed along the NPZ between the Triassic to lower Cenomanian series 
and the mid-Cenomanian sediments (i.e., dating in fact one unconformity inside the Cenomanian). Hence, the early exhumation of the North Pyrenean Paleozoic massifs and the correlated pre-orogenic thinning of the pre-rift sediments during the so-called "preCenomanian phase" have been envisioned since a long time (Casteras, 1965; Mattauer and Proust, 1964, 1965; Durand-Delga, 1964, 1965). Moreover, the significance of this event as a major stage of early extensional deformation in the future NPZ was assumed by most of the Pyrenean geologists (see review in Choukroune, 1976). However, its contemporaneity with the HT metamorphism was not recognized at that time. The link between the ductile deformation in the NPZ metasediments and the HT-LP metamorphism has been later proposed by Vielzeuf and Kornprobst (1984) and Golberg and Leyreloup (1990) and was emphasized more recently by Vauchez et al. (2013) and followers.

\section{Reconstructing the hot, mid-Cretaceous paleomargin of Europa plate from the geology of the North-Eastern Pyrenees: the Salvezines section.}

\subsection{Geological setting}

The eastern NPZ region (Fig. 4) concentrates the best-exposed remnants of the Cretaceous HT extensional event of the Pyrenean belt. The Agly and Salvezines North Pyrenean Paleozoic massifs separate the Saint-Paul-de-Fenouillet (to the north) and Boucheville (to the south) synclines, both cored by the Albian-lower Cenomanian Black Flysch. East of the Agly massif, the Bas-Agly syncline, also cored by the Black Flysch, is thrust northward above the eastern part of the Saint-Paul-de-Fenouillet syncline, both synclines being affected by the counterclockwise virgation of the Gulf of Lions. To the south, the Boucheville syncline and the eastern part of the Agly massif are separated from the Axial Zone by the sub-vertical North Pyrenean Fault. To the north, the edge of the Saint-Paul-de-Fenouillet syncline is thrust 
northward by the North Pyrenean Frontal Thrust (NPFT). To the west, the NPFT splits in two branches bounding another syncline cored by the Black Flysch, the Quillan syncline. North of the NPFT, the foreland comprises the Mouthoumet Paleozoic massif and its Mesozoic cover of platform sediments, the Albian being present only at the southern edge in the NPFT footwall. The latter domain represents the external margin of the Cretaceous extensional basin (Bessières et al., 1989), while the NPZ corresponds to the deep basin domain and provides exposures of metamorphic Black Flysch and pre-rift sediments, Paleozoic basement as well as mantle rocks, allowing observation of the relationships between these various rock-types. A geological cross-section has been chosen which intercepts both the mantle body and the continental basement massifs, as well as Black Flysch depocentres with various degrees of metamorphism (fig. 4). In the following, we first recall a number of important geological features of this area before proposing a balanced restoration of this section (manual restoration by length conservation).

\subsection{Stratigraphic, tectonic and thermal characteristics}

\subsubsection{Sedimentary cover}

The whole study area is characterized by shallow marine Triassic deposits of evaporites, carbonates and clays (Keuper facies). Shallow marine limestones dominated the sedimentation from the Liassic to late Aptian. During the Albian, increasing tectonic instability led to the opening and infilling by the Black Flysch of the major E-W troughs of Quillan, Saint-Paul-de-Fenouillet, Boucheville and Bas-Agly (Berger et al., 1997). The earlymid-Cenomanian period corresponded to a general overflow of the sedimentation (Debroas, 1990; Debroas in Ternet et al., 1997). From the Turonian to early Coniacian, the North Pyrenean basins kept widening with flysch deposition overlapping the North Pyrenean massifs and the northern border of the Axial Zone (Debroas, 1990, 1987). From the Santonian to the Eocene, compression was responsible for the structural inversion of the southern basins 
and northward migration of the northern basins in response to the incipient orogenic bulge (Bessières et al., 1989).

At the southern border of the Mouthoumet massif as well as on the top of the North Pyrenean Agly massif, the pre-rift cover generally appears incomplete. Low-angle extensional tectonic contacts sealed by the transgressive Cenomanian deposits are commonly preserved along the southern border of the Mouthoumet massif. In the Bouchard and Montgaillard areas (fig. 4), geological mapping reveals a wide variety of extensional contacts between the Liassic, Jurassic and Neocomian sediments and the Paleozoic basement rocks, and between the Mesozoic sediments themselves. Such geometries are hardly compatible with contractional deformation and rather indicate extensional tectonics involving normal faults connected to various decollement layers. In the Serre de Bouchard, the tilting toward the NW of a block of the sedimentary cover sealed by the mid-Cenomanian sediments argues for a SE-verging décollement (Bessière 1987; Crochet et al. 1989; Clerc and Lagabrielle, 2014). The preCenomanian deformation is also observed in the Quillan basin where the Cenomanian rests unconformably on Albian sediments previously folded with a syncline geometry (Bois du Lauzet area; fig. 4). The southern limb of the syncline features a fan geometry of the Albian sediments, arguing for synsedimentary folding. Owing to the extensional context, we interpret this structure as the northern limb of an Albian diapir, later squeezed during the Pyrenean compression to become the Bugarach thrust.

Extensional contacts are also observed along the northeastern border of the Agly massif, especially close to the Calce village, where they have been interpreted as the result of a basal truncation of a detached Mesozoic cover (Durand-Delga, 1964; Légier et al. 1987; Vauchez et al., 2013; Clerc and Lagabrielle 2014; figure 5). In this area, the deformation of the Triassic to Albian series is syn-metamorphic (up to ca. $500^{\circ} \mathrm{C}$ ), with tectonic lineations and drag folds (fig. 6) indicating a top to the NNE displacement (Légier et al. 1987; Vauchez et al. 2013). 
Hence, we can infer that the extensional décollements located on the northern and southern margins of the St-Paul-de-Fenouillet and Bas-Agly synclines were all verging toward the syncline axes. More to the south, extensional deformation of the pre-rift cover is represented by discontinuous lenses of Mesozoic metacarbonates along the edges of the Boucheville syncline.

The pre-rift sediments and the thick Black Flysch formations exposed in the study area are variably affected by the HT-LP metamorphism. To the south, the Boucheville basin exhibits some of the highest temperatures $\left(\right.$ circa $600^{\circ} \mathrm{C}$ ) recorded in the NPZ (Golberg and Leyreloup, 1990). Intermediate temperatures $\left(200-450^{\circ} \mathrm{C}\right)$ are recorded in the Bas-Agly syncline (Golberg and Leyreloup, 1990; Vauchez et al., 2013; Chelalou et al., in press). The ages of metamorphism span the late Cenomanian-Turonian (Montigny et al., 1986; Golberg and Maluski, 1988; Albarède and Michard-Vitrac, 1978; cf. synthesis in Clerc et al., 2015). Although precise paleothermometric analyzes are still lacking, the rocks exposed in the northern depocentres (Saint-Paul-de-Fenouillet and Quillan) do not present mineralogical evidence of a well-developed metamorphic imprint, which is also typically lacking north of the NPFT.

\subsubsection{Paleozoic basement}

The Mouthoumet massif results from the stacking of several allochtonous units during the Variscan orogeny. Outcropping strata range from the Ordovician to the Carboniferous (e.g., Berger et al., 1997). As it is stated above, the Mouthoumet massif represents the proximal, non-metamorphic northern margin of the mid-Cretaceous basin.

Similarly to most of the other North Pyrenean massifs, the Agly and Salvezines massifs are lens-shaped crustal blocks aligned along the NPZ axis. Both massifs show an internal 
structure tilted northward, so that the oldest units and those having the highest metamorphic grade crop out on their southern side, in contact with Mesozoic metasediments displaying the highest grades of the HT/LP Cretaceous metamorphism (fig. 2). Their internal structure reveals a condensed crust, passing downwards from the Carboniferous sediments to the migmatitic and granulitic facies, in a few kilometers only (e.g., $5 \mathrm{~km}$ in the Agly massif; Paquet and Mansy, 1991). Such a tilted attitude and condensed internal structure is common to many other North Pyrenean massifs (Clerc and Lagabrielle, 2014). Most of the metamorphism affecting the North Pyrenean massifs is found to be late Paleozoic (e.g. Olivier et al., 2004). For some authors, the condensed structure of the crust results from either Variscan transpressive doming (Olivier et al., 2004; Olivier et al., 2008) or late Variscan extensional events (Bouhallier et al., 1991). For other authors, the thinning of the crust is the result of the partial (re)activation of mylonitic extensional shear zones during the Cretaceous (Passchier, 1984; Costa and Maluski, 1988; St Blanquat et al., 1990; Paquet and Mansy, 1991; Vauchez et al., 2013). In addition, the crust suffered a widespread hydrothermal alteration as revealed by albitization and dequartzification, well developed in the Salvezines massif and in other North Pyrenean massifs, and dated between 110 Ma and 92 Ma (Boulvais et al., 2006; 2007; Poujol et al., 2010, Fallourd et al., 2014). In the Salvezines massif, albitization occurred at temperatures estimated around $400^{\circ} \mathrm{C}$ for pressures of $150-200 \mathrm{MPa}$ (Pascal, 1979; Boulvais et al., 2006). Further west in the St Barthélémy massif, a shear zone involved fluid circulations and $\mathrm{Mg}$ enrichment with talc precipitation linked to continuous shearing dated between 112 and $97 \mathrm{Ma}$ (Schärer et al., 1999). These features and their contemporaneity with the HT anomaly and the exhumation of numerous ultramafic bodies in the immediate vicinity of the deepest levels of the North Pyrenean massifs point to severe crustal thinning during the Cretaceous. At the scale of the whole NPZ, the ages of the Cretaceous metasomatism affecting the Paleozoic basement of the North Pyrenean massifs are slightly older (Aptian to 
early Cenomanian; Boulvais et al., 2007; Schärer et al., 1999; Poujol et al., 2010; Fallourd et al., 2014) than the ages of the metamorphic assemblages in the Mesozoic cover (Albian to Santonian; late Cenomanian-Turonian in the study area; Albarède and Michard-Vitrac, 1978; Golberg et al., 1986; Montigny et al., 1986; Golberg and Maluski, 1988). This evolution in the ages of the metamorphism in both the basement and the cover suggests an upward, progressive migration of the thermal anomaly through the continental crust (Clerc et al., 2015).

\subsection{The "Pre-Cenomanian phase" along the Salvezines section}

The descriptions above show that the "pre-Cenomanian phase" is well expressed both (i) in the Mesozoic cover of the Mouthoumet massif where the pre-rift sediments form isolated extensional rafts sealed by the Cenomanian transgression, and (i) in the Quillan syncline, where the pre-Cenomanian unconformity argues for an early stage of syncline formation related to an Albian diapir.

In the southern part of the study area, where the metamorphic imprint is strong, the preCenomanian unconformity is not observed due to erosion. However, the early phase of deformation of the pre- and syn-rift Mesozoic sediments is particularly well recorded. This event led to the partial or entire attenuation of the pre-Cenomanian series, which are discontinuous or boudinaged at the mapping scale. At the outcrop scale, this deformation is ductile, characterized by a foliation corresponding to bedding-normal flattening and beddingparallel boudinage. This is well exemplified at Belesta and Sournia (fig. 7). In the pre-rift of the Agly massif cover, the foliation bears a SSW-NNE-oriented mineral lineation (Vauchez et al., 2013). Recumbent folds of millimeters to hundreds of meters scale are commonly observed. Note that such folds are often described in similar major extensional units (Harris et al., 2002) and do not necessarily imply regional compression. In the NPZ, some of these folds 
correspond to drag folds along shear zones (fig. 6). Based on EBSD study of calcite deformation fabrics in the pre-rift carbonates of the Agly massif cover, Vauchez et al. (2013) have shown that this ductile extensional deformation developed at temperature around $400^{\circ} \mathrm{C}$. These temperatures are comparable to those of the late Cenomanian-Turonian metamorphism in the Bas-Agly syncline which is located close $(2 \mathrm{~km})$ to the north, in structural continuity with the Agly massif cover. Hence, the ductile deformation of the pre-rift cover of the Agly massif can be ascribed to the Cretaceous tectonic event. However, there is no stratigraphical evidence that this tectonic-thermal event ended with the "pre-Cenomanian" unconformity and did not continued until a more recent date in the late Cretaceous.

Globally, these characters of the "pre-Cenomanian" phase along the Salvezines section depict a zonation of the structure of the margin comprising a proximal part in the north, affected by a "cold" deformation with cover decollement and diapirism in the Triassic evaporites, and a distal part in the south where the Paleozoic basement, pre-rift carbonate and syn-rift flysch are affected by syn-metamorphic ductile deformation. The association of these two types of margin architecture along a single and comprehensive section makes this area the first example of inverted hot passive margin described so far.

\subsection{Balanced restoration of the Salvezines cross-section:}

The cross-section presented in figure 8 runs from the proximal margin represented by the Mouthoumet massif in the north, to the hot Boucheville basin, south of the Salvezines Paleozoic massif. The section is orthogonal to the main compressional structures but is probably oblique to the direction of extension (cf. section 2). However, it presents several characteristic features that allow for a tentative reconstruction of the extensional domain. From north to south, it cuts through the following domains (fig. 4): 
- The Alet-les-Bains block represents the most proximal segment of the margin. The outcropping basement comprises a succession of Ordovician to Carboniferous sediments. Remnants of Triassic clays and evaporites (Keuper) are found on its southern border, unconformably overlaid by Campanian sandstones, followed by Maastrichtian to Eocene sediments (Crochet et al. 1989; fig. 4). The Alet-les Bains block is bounded by two steep south-dipping reverse basement faults, which separate it from the Eocene Limoux basin to the north and the Cardou block to the south. Overturned limbs in the Cretaceous-Tertiary strata occur in the footwalls of these faults.

- The Cardou block also presents residual Keuper sediments together with discontinuous extensional rafts of Jurassic and lower Cretaceous sediments, unconformably overlaid by the Cenomanian limestones, marls and sandstones (i.e., Montgaillard and Bouchard areas in fig. 4). The Cenomanian is followed by the upper Cretaceous to Paleocene succession. The Albian sediments only outcrop at the southern edge of the Cardou block, in overturned thrust slices located in the footwall of the NPFT.

- The cover of the Bois du Lauzet block comprises the thick Albian formations of the Quillan basin, featuring syn-sedimentary folding with fan geometry below the unconformable Cenomanian limestones (Bois du Lauzet area, fig. 4). This cover succession is folded in the Quillan syncline and detached in the Keuper sediments. The northern limb of the syncline is thrust by the NPFT above the Cardou block. The occurrence of lenses of Keuper sediments along the thrust between the Albian sediments present both in the hanging wall and footwall argue for the occurrence of a discontinuous pre-rift cover, possibly comprising extensional rafts at depth. The southern limb of the Quillan syncline is overturned below the Bugarach thrust. The section construction implies that the top of the basement is at greater depth in the Bois de Lauzet block than in the Cardou block, suggesting that the NPFT ramp corresponds to the reactivation in the sedimentary cover of a south-dipping pre-compressional normal fault 
not inverted in the basement. As it is discussed above, it is possible that the pre-Cenomanian folding of the Albian corresponds to a diapir formed in the Triassic evaporites above the basement fault and then squeezed during the Pyrenean compression to form the Bugarach thrust. Similarly, the occurrence along the NPFT of Triassic evaporites separating Albian sediments both in the normal polarity hanging wall limb and reverse polarity footwall limb may correspond to a welded Cretaceous diapir.

- The Saint-Paul-de-Fenouillet syncline, cored by the Black Flysch is also detached in the Keuper sediments. Its northern limb is thrust onto the Bois du Lauzet block by the Bugarach thrust.

- The Salvezines Paleozoic massif outcrops in the core of an anticlinal beneath the Mesozoic succession of the NPZ and is affected by strong albitization during the Albian (cf. above). It is constituted of 2 units separated by a low temperature mylonitic shear zone: (i) the allochtonous Caunil unit, made of Paleozoic metasediments, and (ii) the autochtonous Salvezines unit made of gneisses and leucogranite (Demange and Pascal, 1979). A small outcrop of mantle peridotites occurs at its southern border, in direct contact with the Mesozoic sediments.

- The Boucheville syncline, squeezed between the Paleozoic of the Salvezines massif to the north and of the Axial zone to the south, mainly comprises the Black Flysch, intensely metamorphosed and deformed (Choukroune, 1973, Golberg and Leyreloup, 1990). Spindleshape lenses of Neocomian or Jurassic strata occur along the boundaries of the Boucheville syncline, indicating that the Black Flysch rests over the ductily dismembered pre-rift sedimentary cover.

The Paleozoic basement blocks of Cardou and Alet-les-Bains are thrust northward over the Tertiary deposits by high angle reverse faults. Further south, the style of the Pyrenean 
compression can hardly be evaluated in the Paleozoic basement since the latter is largely covered by the Mesozoic sediments. However, the cross-section construction implies that the NPFT and Bugarach thrust correspond to thin-skinned detachments in the Triassic Keuper facies rooted to the south below the antiformal Salvezines massif. The Mesozoic series of the Saint-Paul-de-Fenouillet and Quillan synclines are hence transported northward above the Triassic décollement level, and represent the former cover of a basement now underthrust below the southern NPZ and the Axial Zone. Along the studied cross-section, length estimates indicate an offset of circa $3 \mathrm{~km}$ for the Bugarach thrust and $2.4 \mathrm{~km}$ for the NPFT and a total shortening of about $21 \mathrm{~km}$ on the whole cross-section taking into account the thrust-related folds.

The balanced restoration proposed in figure 8 is done at the top of the Albian-lower Cenomanian Black Flysch. In our attempt to restitute as truthfully as possible the size of the opened domain, we reported the length of the different units determined from the present cross-section. However, in such a case of superimposed deformations, the effects of the first, extensional phase of deformation are hardly integrated. As described above, the Mesozoic cover underwent drastic ductile deformation and boudinage during continental thinning. Hence the length and volume of the pre-rift material can hardly be evaluated with precision. In our restoration we have integrated this constraint by representing to the south the ductile boudinage of the cover in a style similar to that observed on the edges of the St Paul-deFenouillet and Boucheville basins, and to the north, tilted blocks on listric normal faults as observed north of the NPFT .

Similarly, the basement is affected by steep south-dipping normal faults in the northern area (Alet-les-Bains and Cardou blocks) corresponding to the proximal, cold part of the margin, and by ductile boudinage in the metamorphic domain of the NPZ. Below the Boucheville basin, extreme boudinage of the crust resulted in the exhumation of the upper mantle that may 
have been in contact with the sedimentary cover and which a slice was pinched during the inversion between the Boucheville syncline and Salvezines massif.

The extension of the domain corresponding to the Boucheville basin can hardly be estimated because no outcrops allow determining a possible anchorage of the pre-Albian cover on the Axial Zone. In the interpretation proposed in figure 8, the domain running from the NPF to the northern limit of the Cardou block (southwestern termination of the Mouthoumet massif) is $42.5 \mathrm{~km}$ wide at the end of the Albian, reduced to $25 \mathrm{~km}$ nowadays, which represents a shortening of $17.5 \mathrm{~km}$.

\section{$\underline{3.5}$ Discussion and general implications of the Salvezines section restoration}

Several remarkable geological features are highlighted by the restoration of the Salvezines cross-section. In the following, we discuss their major implications.

\section{5.a. Decollement levels and cataclastic breccias}

At the external part of the margin and in the cover of the Agly massif, thinning and extensional deformation of the pre-rift sediments occurred by the means of normal faults and basal truncation of the pre-Albian Mesozoic sediments. This tectonic process affected the Triassic, Jurassic and Neocomian sediments and metasediments.

The importance of extensional tectonics implies motions along decollement levels and detachment faults. At least three decollement levels are recognized in the pre-rift strata of the Pyrenean realm. A first one is located in the Silurian ampelites, which has been activated during the Variscan orogeny, and might have been reactivated during the Mesozoic (Bessière, 1987). Two other decollements are identified in the Mesozoic succession. The major one is located in the Triassic evaporites and clays, and the other one in the upper Liassic marls (Durand-Delga 1964; Bessière 1987; Berger et al. 1993; Fonteilles et al. 1993; Jammes et al. 
2009; Lagabrielle et al. 2010; Jammes et al. 2010). All these levels may have been active in the study area, but the section in Figure 8 shows that the Triassic decollement level played the prominent role. We investigated more specifically the Mesozoic formations at the northern rim of the Agly massif. Here, cataclastic breccias are observed in many places at the base of the pre-rift sedimentary sequences, on top of the Paleozoic basement confirming important displacements along the Triassic decollement level (fig. 5). An important feature is that some of these breccias contain clasts of ductily deformed Mesozoic marbles, often with isolated isoclinal fold hinges (fig. 5, 9). This suggests that the cataclastic breccias are the witness of a decollement layer that recorded an evolution from ductile to brittle behavior.

\section{5.b. Importance of the pre-Albian events for crustal evolution.}

The continental crust in the southern part of the section underwent a severe thinning since a rapid transition is now observed from shallow levels, such as Devonian or Carboniferous sediments to high grade migmatites and granulites in a few kilometers (e.g., $5 \mathrm{~km}$ in the Agly massif, Paquet and Mansy, 1991). By now, it is still unclear whether this structure is inherited from the late-Variscan (Bouhallier et al., 1991; Olivier et al., 2004) or results from the Cretaceous extensional event (Paquet and Mansy 1991; Vauchez et al. 2013). In the sections above, we mainly focused on the events that occurred during the late Aptian to early Cenomanian rifting. However, previous events may have also played a role in the tectonic evolution of the margin. After the Variscan orogeny, the Permian events are characterized by the opening of asymmetrical basins and by a magmatic activity (Lago et al., 2004). A first Triassic aborted rift followed by a possible initiation of the drift of Iberia as soon as the Jurassic (Jammes et al., 2009) might have resulted in the individualization of numerous crustal blocks responsible for topographic heterogeneities in the region. This is well illustrated by the paleogeography of the Aptian deposits, characterized by the juxtaposition of thick anoxic marl depocentres bounded by reef platforms (Urgonian facies) and emerged 
topographic highs attested by bauxites deposits (Combes, 1969; Peybernès 1976; Combes and Peybernès 1989).

We may wonder how these multiple rifting events have affected the rheology and structure of the continental lithosphere before the mid-Cretaceous rifting. The two main magmatic events (Permian and Triassic) may have changed considerably the thermal structure of the continental crust and subcontinental mantle. In addition little is known about the thickness of the continental crust at the end of the Variscan orogeny in the area of the future NPZ and the reactivation of Variscan structures is often proposed albeit poorly understood (Barruol et al., 1998; Diaz et al., 2006). Was the crust typically $30 \mathrm{~km}$ thick before the Cretaceous rifting? If a left-lateral displacement of Iberia with respect to Europe actually occurred before the Albian rifting (cf. above, section 2), it probably participated to the thinning and weakening of the plate boundary. All these uncertainties lead us to be cautious when proposing detailed mechanisms for extreme crustal thinning and mantle exhumation during the Cretaceous. The future NPZ may have been the site of a concentration of specific parameters leading to a very original mode of continental rifting and mantle exhumation that may have applied to a prethinned crust. The only robust constraints come from i) the thermal evolution of the pre-rift cover with very high temperatures at the base of extensional basins during syn-rift sediment deposition; ii) the juxtaposition of pre-rift Mesozoic metasediments on top of unroofed subcontinental mantle; and iii) the mid-Cenomanian unconformity drawing the pattern of the "Pre-Cénomanian phase" of the authors.

\section{5.c. Ductile deformation at the base of the basin and coeval Cretaceous sedimentation: two} major constraints

In this section, we show how observations in the metamorphic terranes of the study area outline two major geological constraints to be integrated in any new model of evolution. 
- The first major constraint derives from the absolute dating of metamorphic sediments. It implies that during the ductile deformation of the pre-rift cover, flysch sedimentation was going on. Therefore one must admit that the flysch succession acted as a blanket, allowing temperatures to reach their maximum values in the pre-rift (up to $600^{\circ} \mathrm{C}$ in the Boucheville basin, up to $450^{\circ} \mathrm{C}$ in the Bas-Agly synform) during the late Cenomanian-Turonian (Clerc et al., 2015). The HT-LP metamorphism is also recorded in the Albian Black Flysch formations themselves, with maximum pressures of $50-400 \mathrm{MPa}(\approx 1.3 \mathrm{~km}$ to $10 \mathrm{~km}$ depth), indicating that sediments younger than the Albian, and presently eroded in the study area, have been deposited above them (Bernus-Maury, 1984; Goujou et al., 1988; Golberg and Leyreloup, 1990). Where they are preserved, the Cenomanian-Turonian sediments were also metamorphosed and heated, with temperatures up to $350^{\circ} \mathrm{C}$ recorded in the Aulus basin (Clerc et al., 2015). Radiogenic ages of the HT-LP metamorphism ranging from the Albian to the Coniacian in various parts of the NPZ (Albarède and Michard-Vitrac 1978; Golberg et al. 1986; Montigny et al. 1986; Clerc et al., 2015) point to a 20-25 Ma long development of the HT metamorphic imprint at the base of the sedimentary pile and to the continuous sedimentation above the metamorphic sediments.

- The second major constraint to take into account is that coeval metamorphism and sedimentation developed within a tectonically active domain dominated by continuous extension. Therefore, ductile deformation and boudinage occurred as the pre-rift Mesozoic cover was transported along with the extending and moving floor of the basins. Decollements levels inside the sedimentary pile may have favored decoupling between units of variable metamorphic evolution. Extensional deformation of the pre-rift sequence below the flysch pile led to the progressive exhumation of the deeper units that suffered an evolution from ductile to brittle deformation conditions. The cataclastic monomictic breccia reworking metamorphic clasts in the Mesozoic series are the marks of this transition from ductile to 
brittle deformation (fig. 5 and 9). These constraints are discussed in section 5 and integrated into a new model of passive margin evolution.

\section{Comparison with current Atlantic-type distal margins}

Numerous high quality industrial seismic reflection profiles have now been acquired along passive margins worldwide. Stunningly increasing resolution over the past decades lead to unravel unexpected structures. In this section we present and compare an example of a magma-poor passive margin from West Africa with the Cretaceous passive margins fossilized in the Pyrenees.

The distal domain of the West African non-magmatic margin is generally represented with an important sag basin (Contrucci et al., 2004; Moulin et al., 2005). The sag basin is generally described as "banana-shaped" and "subsiding vertically without differential tilting" (Aslanian et al., 2009) resting on a "highly thinned, little faulted continental crust" (Unternehr et al., 2010). The section of fig. 10, acquired across basin of the central segment of the West African margin images the deep sediments and the crust. A set of listric normal faults dipping toward the continent and horizontalizing within the continental crust (thick black lines) delimitates smooth deca-kilometric continental units having some characteristics of classical tilted block, with seaward tilting of the top basement and fan-like geometry of syn-rift sedimentary sediments (light green). But the crust also present some characteristics suggesting a regional fabric made up of crustal phacoids delimited by anastomozing shear zones. These characteristics comprise very low angle normal faults and numerous subhorizontal reflectors delimitating 5 to $20 \mathrm{~km}$-long spindle-shaped patches of continental crust. Comparable discontinuities identified in the lower crust offshore Britain were interpreted as anastomozed semi-brittle shear zones (Reston, 1988). Similar crustal units sharing characteristics with both tilted blocks and crustal boudins are described along the magmatic 
margins of the Møre and Vøring basins, where they are interpreted as disrupted portions of the roof of a core complex, horizontalizing and rooting in a ductile and boudinaged mid- to lower-crust (Osmundsen and Ebbing, 2008).

This geometry leads to a crust thinner than one would normally expect with a classical block tilting mechanism. As a consequence, the syn-rift sediments rest over the upper crust in the proximal margin, but they directly overly the exhumed lower crust and/or mantle peridotites in the distal margin as in the models IIa of Huismans and Beaumont (2014). In particular, the seismic profile in figure 10 shows that, in the most distal part, the intermediate syn-rift sequence (light green) (i) rests directly above a lower crust lens through a bedding-parallel contact and against mantle rocks by a hanging wall ramp, and (ii) is overlaid by a detachment above which the late syn-rift sequence is affected by listric faults and roll-over structures. Eastwards, this intermediate syn-rift unit thins and rests above an early syn-rift unit (blue), which rests itself above the lower crust lens through a hanging wall ramp on the basinward side, and on an upper crust lens by a bedding-parallel contact on the landward side. This suggests that the syn-rift pile is affected by multiple detachment levels and associated rollover structures and dragged over exhumed crustal and mantle rocks for up to 5 to $10 \mathrm{~km}$.

Several features shown on this seismic profile can be compared to typical features of the NPZ:

1) A high thermal regime of the hyper-extended domain, suggested by the rather ductile style of the deformation (spindle-shape crustal patches limited by numerous low angle reflectors).

2) The development of syn-rift basins over strongly thinned continental crust, with basin floors locally made of exhumed material of deep origin (continental crust, mantle peridotites)

3) A thinning mechanism involving the activation of very low angle normal faults, nearly parallel to the stratigraphic contacts at different levels in the stratigraphic pile, both in the 
crust and syn-rift cover. These contacts are responsible for relative lateral displacements of the different stratigraphic units, possibly leading to the exhumation of the older pre- or synrift units from beneath the younger syn-rift units.

4) The formation of rollover folds affecting the syn-rift sediments above these detachments.

We note that on the profile shown in figure 10, the occurrence of a salt layer at the base of the post-rift sequence resulted in the gravitational sliding of the latter, a process also described in the post-rift upper Cretaceous strata of the southern Pyrenees (McKlay et al., 2004).

\section{Discussion: Extreme thinning at hot passive margins and the behavior of the pre-rift} cover.

Considering the architecture of distal passive margins as presented above together with our restoration of the Salvezines cross section allow proposing a general evolutionary model for the pre- and syn-rift sequence of the North-Eastern Pyrenean rifted margin (fig. 11). This conceptual model integrates one of the major constraints exposed above and which can be summarized as follows: flysch sedimentation is continuous during ductile deformation of sediments at the base of the sedimentary pile.

Our model is based on a simplified geological sequence having the characteristics of the Northeastern Pyrenean region. It includes a continental basement, a first decollement level in Triassic evaporites, a level of layered pre-rift carbonates and a cover of syn-rift flysch. The carbonates are able to deform by crystalline plasticity of calcite under HT conditions and therefore can localize a secondary discontinuity level at their roof. The model can be described in three steps as follows (fig. 11): 
(1) Restoration at an early rifting stage (fig. 11a) shows moderate extension with crustal thinning accommodated through normal faults in the upper crust passing downward to ductile shear zones. As it is detached above the Triassic evaporitic layers, the carbonate level tends to remain in the most thinned and subsiding domains while the syn-rift Black Flysch is being deposited above.

(2) Restoration at a mid-rifting stage (fig. 11b) shows strong ductile thinning of the crust in response to heating due to rapid mantle uplift. Due to the fact that the syn-rift sediments act as a blanket, the pre-rift carbonates are also affected by syn-metamorphic ductile deformation and boudinage while they are transported along with the extending and moving basement of the basin. Progressively, the initial plasticity of the evaporite layers decreases as they get smeared and consumed by fluid circulations (Dauteuil and Ricou, 1989; Clerc et al., 2015; Boulvais et al., in press). In turn, due to their increasing plasticity, the HT marbles progressively accommodate the whole deformation at the base of the basin, involving foliation of calcite, boudinage of the most dolomitic beds, drag folding and truncations by low angle normal shear bands. The lower part of the syn-rift flysch sequence is also progressively affected by HT metamorphism and ductile deformation with bedding-parallel foliation and boudinage. Sliding of the pre-rift carbonates in the deep domain results in the local tectonic denudation of the margins where carbonates remnants form isolated rafts tilted on listric faults.

(3) Restoration at the final rifting stage (fig. 11c) shows the complete thinning and boudinage of the crust and local exhumation of the sub-continental mantle, which is by place in tectonic contact with the pre- or syn-rift sediments. Continuous extension of the basin floor leads also to the progressive exhumation of the metamorphic pre-rift sediments which are progressively 
extracted from below the syn-rift cover by the activity of the secondary detachment level at their roof. However, marine sedimentation continues during deformation and extraction of the pre-rift sediments, maintaining a complete blanket of flysch. In this process, the units of ductily deformed Mesozoic metasediments that are withdrawn from the base of the sedimentary pile reach shallower and cooler environments and hence cross the ductile-brittle transition, as it is recorded in cataclastic tectonic breccias reworking clasts of metamorphic carbonates (Fig. 12a). At the same time, metamorphism of the pre-rift carbonates continues in areas away from the exhumation zone.

The precise dating of the last stages of exhumation (rifting) remains tentative. In our restoration, we have assumed that rifting did not end with the "pre-Cenomanian" unconformity but may have continued during the Cenomanian-Turonian, as suggested by the fact that cataclastic deformation in the Agly massif cover post-dates syn-metamorphic ductile deformation, while metamorphism is dated to the late Cenomanian-Turonian a few kilometers away in the Boucheville and Bas-Agly synclines. This assumption is also consistent with the occurrence of conglomerates in the flysch successions of this age further west along the NPF and locally within the ZNP (Debroas, 1987; Debroas, 1990; Debroas in Ternet et al., 1997). In this interpretation, the metamorphism recorded in the Boucheville and Bas-Agly synclines would be contemporaneous of the final stage of rifting when temperature reached its maximum in the basin-fill below the flysch blanket of these depocenters while the Agly massif and its cover were exhumed. This implies that the "pre-Cenomanian" unconformity would not represent the "post-rift" unconformity at the scale of the whole margin, but recorded the Cenomanian transgression on the northern basin margin, that emerged during the Albian and where the Triassic decollement became inactive while ductile deformation continued in the distal margin. 
Figure $12 \mathrm{~b}$ shows an alternative to Fig. 12a where continuous extension leads to exhumation and sedimentary reworking of the subcontinental mantle and its metacarbonate cover, as it occurred further west in the Lherz (Lagabrielle and Bodinier 2008; Lagabrielle et al., 2010; Clerc et al., 2012; Lagabrielle et al., 2015) and the Urs, Caussou and Bestiac areas (St Blanquat et al., 2015).

\section{Conclusions.}

The constraints that lead us to propose a model of exhumation of pre-rift sediments strictly derive from the observation and interpretation of simple, obvious field features in the metamorphic regions of the North Pyrenean Zone, in particular along the described Salvezines section. These features are as follows:

1. The mid-Cenomanian unconformity, related to the "pre-Cenomanian" phase of the authors, which implies the deformation of the pre-Cenomanian series before the deposition of the Cenomanian-Turonian flysches.

2. The HT deformation of the marbles and boudinage of the most dolomitic layers, which is consistent with ductile extensional deformation of the pre-rift cover (Vauchez et al., 2013).

3. The pre-inversion (Albian to Santonian at the scale of the NPZ; late Cenomanian-Turonian on the Salvezines section) age of the HT metamorphic episode, which indicates a syn- to postextensional heating of the rifted domain under low pressures.

4. The fact that these events took place within an environment of continuous expansion of the basin floor. 
Our model involves a progressive extraction of the pre-rift sedimentary cover from below the flysch pile, up to a more shallow position. Through cooling, the deformation at first ductile, became brittle, as shown by the presence of intraformational layers of tectonic breccias reworking clasts affected by an earlier ductile deformation. The ultimate evolution of this process could lead to reworking of these exhumed metacarbonates in sedimentary breccia such as those of the Lherz area. However, refinement of dating of the various steps of ductile and cataclastic deformation are still needed to better constrain the interpretation of the final stages of rifting. The processes involved can help to understand the geometries imaged across present-day passive-margins and have to be taken into consideration when considering the thermal history experienced by the pre- and syn-rift sediments deposited in the distal part of these margins. 


\section{Figure caption:}

Figure 1. Structural sketch of the Pyrenean range. NPFT: North Pyrenean Frontal Thrust, NPF: North Pyrenean Fault, SPFT: South Pyrenean Frontal Thrust.

Figure 2. Simplified geological map of the North Pyrenean Zone, compiled after Choukroune and Seguret (1973), Jammes et al. (2009) and the 1/50 000 geological maps of the BRGM.

Figure 3: The North Pyrenean Zone as early represented by Casteras (1933) and Ravier (1959). The authors emphasized a rather smooth undulation of the Paleozoic basement controlling the deposition of the Albian-lower Cenomanian Black Flysch. Note that the midCenomanian sediments about to be deposited will unconformably cover both the Black Flysch and pre-Albian strata. This geometry defines the "Pre-Cenomanian phase".

Figure 4. Simplified geological map of the study area. Redrawn after the BRGM 1/50 000 geological maps by Ovtracht et al. (1977), Ellenberger et al. (1985), Berger et al. (1997), Fonteilles et al. (1993), Crochet et al. (1989), and the maps by Golberg (1987) and Golberg and Leyreloup (1990).

Figure 5. Up: Map of the northeastern termination of the Agly Paleozoic massif (location in figure 4) presenting evidences of basal truncations of the Mesozoic cover. The basal décollement is marked out by numerous monomictic tectonic breccias reworking ductily deformed Mesozoic metasediments (a to f).

Figure 6. Photograph and interpretation of boudinage and northward verging drag fold in the Triassic and Liassic cover of the Agly massif (42 $45^{\prime} 1.53 " \mathrm{~N} ; 2^{\circ} 44^{\prime} 13.38^{\prime \prime} \mathrm{E}$; location in figure $5)$.

Figure 7. Photographs illustrating the ductile deformation observed in the Albian metasediments of the Boucheville basin. a) Strong foliation, boudinage and drag folds in the 
metapelites $\left(42^{\circ} 45^{\prime} 0.16^{\prime \prime} \mathrm{N} ; 2^{\circ} 29^{\prime} 32.50 " \mathrm{E}\right)$. b) Boudinaged quartz exudates within the Albian flyschs (North of Le Vivier). c) and d) Boudinaged silicic layers within Triassic marbles (NW Bélesta).

Figure 8. a) Structural section across the Mouthoumet, St Paul de Fenouillet, Salvezines and Boucheville areas (location: $\mathrm{AB}$ in figure 4). b) $\mathrm{AB}$ profile restored at the roof of the AlbianCenomanian Black Flysch.

Figure 9. An example of brittle deformation affecting previously ductily deformed marbles in the Calce area $\left(42^{\circ} 45^{\prime} 1.53^{\prime \prime} \mathrm{N} ; 2^{\circ} 44^{\prime} 13.38^{\prime \prime} \mathrm{E}\right.$; location in figure 6$)$. The ductile foliation preserved on the upper and lower parts of the picture is progressively dismembered toward the center, with increasing clast displacement and clast size reduction.

Figure 10. Line-drawing and interpretation of a two-way travel time seismic reflection profile of the present Atlantic passive margin offshore West Africa (courtesy of Total).

Figure 11. a, b and c) Three steps conceptual model of margin evolution and related exhumation of metamorphic pre-rift Mesozoic sediments, based on features characteristic of the North-Eastern Pyrenean domain (step by step description in the text).

Figure 12. Two alternative details of the final stage of rifting and related exhumation. a) Zoom on figure 11 showing extraction of the pre-rift carbonates from below the syn-rift flysch and related transition from ductile to brittle deformation. b) Possible evolution where continuous extension leads to exhumation and sedimentary reworking of the subcontinental mantle as described in the Lherz and other areas (references in the text). 



\section{Acknowledgements:}

Web are grateful to Total, Schlumberger Multiclient and Petrolin for providing the seismic data. This work was funded by the CNRS and Total through a Ph.D. grant to C. Clerc. 


\section{References}

Albarède, F. and Michard-Vitrac, A., 1978. Age and significance of the North Pyrenean metamorphism: Earth and Planetary Science Letters, 40, p. 327-332, doi: 10.1016/0012-821X(78)90157-7.

Aslanian, D., Moulin, M., Olivet, J.-L., Unternehr, P., Matias, L., Bache, F., Rabineau, M., Nouzé, H., Klingelheofer, F., Contrucci, I. and Labails, C., 2009. Brazilian and African passive margins of the Central Segment of the South Atlantic Ocean: Kinematic constraints: Tectonophysics, 468, p. 98-112, doi: 10.1016/j.tecto.2008.12.016.

Barruol, G., Souriau, A., Vauchez, A., Diaz, J., Gallart, J., Tubia, J. and Cuevas, J., 1998. Lithospheric anisotropy beneath the Pyrenees from shear wave splitting: Journal of Geophysical Research, 103, p. 053.

Berger, G.M., Bessière, G., Bilotte, M. and Viallard, P., 1997. Carte géol. France (1/50 000), feuille Tuchan (1078):

Berger, G.M., Fonteilles, M., Leblanc, D., Clauzon, G., Marshal, J.P. and Vautrelle, C., 1993. Notice explicative, carte géol.. France (1/50 000), feuille Rivesaltes (1090). Orléans : BRGM, 117 p. Carte géologique par Fonteilles M., Leblanc D., Clauzon G., Vaudin J.-L., Berger G.-M. (1993):.

Bernus-Maury, C., 1984. Etude des paragéneses caractéristiques du métamorphisme mésozoïque dans la partie orientale des Pyrénées [Thèse]: 253p. p.

Bertrand, L., 1940. Sur la structure géologique du versant nord des Pyrénées: 204, p. 205-283.

Bessière, G., 1987. Modèle d'évolution polyorogénique d'un massif hercynien: le Massif de Mouthoumet (Pyrénées audoises) [Thèse]: 314 p.

Bessière, G., Bilotte, M., Crochet, B., Peybernès, B., Tambareau, Y. and Villatte, J., 1989. Notice explicative, Carte géol. France (1/50 000), feuille Quillan (1077): BRGM, Orléans.

Bodinier, J.-L, J. Fabriès, J.-P. Lorand, et C. Dupuy. 1987. « Geochemistry of amphibole pyroxenite veins from the Lherz and Freychinède ultramafic bodies (Ariège, French Pyrenees) ». Bull. Mineral. 110: 345- 58.

Bouhallier, H., P. Choukroune, et M. Ballèvre. 1991. « Evolution structurale de la croute profonde hercynienne ; exemple du massif de l'Agly (Pyrénées orientales, France). » C. R. Acad. Sci. Paris, serie II 312: 647- 54.

Boulvais, P., in press. Fluid generation in the Boucheville Basin as a consequence of the North Pyrenean metamorphism: Comptes Rendus Geosciences, in press.

Boulvais, P., de Parseval, P., D’Hulst, A. and Paris, P., 2006. Carbonate alteration associated with talc-chlorite mineralization in the eastern Pyrenees, with 
emphasis on the St. Barthelemy Massif: Mineralogy and Petrology, 88, p. 499-526, doi: 10.1007/s00710-006-0124-X.

Boulvais, P., Ruffet, G., Cornichet, J. and Mermet, M., 2007. Cretaceous albitization and dequartzification of Hercynian peraluminous granite in the Salvezines Massif (French Pyrénées): Lithos, 93, p. 89-106, doi: 10.1016/j.lithos.2006.05.001.

Casteras, M., 1933. Recherches sur la structure du versant nord des Pyrénées centrales et orientales: Serv. Carte Géol. France, XXXVII, p. 515p.

Casteras, M., 1965. Remarques sur l'Albien du bassin de Quillan (Aude): observation à propos d'une note de MM. Mattauer et F. Proust: C. R. somm. Soc. geol. Fr.,, p. 6061.

Chelalou, R., Nalpas T., Bousquet R., Prevost M., Lahfid A., Poujol M., Ringenbach J.-C. and Ballard J.-F., 2015. New sedimentological, structural and paleo-thermicity data on the Boucheville basin (eastern North Pyrenean Zone, France):: Comptes Rendus Géosciences, in press.Choukroune, P., 1973. La brèche de Lherz dite 'd'explosion liée à la mise en place des lherzolites' est une brèche sédimentaire d'âge Cénozoïque.: C. R. Sceances Acad. Sci. Ser. D, 277, p. 2621-2624.

Choukroune, P., 1976. Structure et Evolution Tectonique de la Zone Nord Pyrénéenne: Analyse de la déformation dans une Portion de Chaîne à Schistosité Subverticale: Mem. Soc. Geol. Fr. Ser.,, p. 176 pp.

Choukroune, P. and ECORS Team, 1989. The Ecors Pyrenean deep seismic profile reflection data and the overall structure of an orogenic belt: Tectonics, $\mathbf{8}, \mathrm{p}$. PP. 23-39, doi: 198910.1029/TC008i001p00023.

Choukroune, P. and Mattauer, M., 1978. Tectonique des plaques et Pyrénées: Sur le fonctionnement de la faille transformante nord-Pyrénéenne; comparaisons avec les modèles actuels: Bulletin de la société géologique de France, 20, p. 689-700.

Choukroune, P. and Séguret, M., 1973. Carte structurale des Pyrénées: ELF-ERAP.

Clerc, C., Boulvais, P., Lagabrielle, Y. and Blanquat, M., 2013. Ophicalcites from the northern Pyrenean belt: a field, petrographic and stable isotope study: International Journal of Earth Sciences,, p. 1-23, doi: 10.1007/s00531-013-0927$\mathrm{z}$.

Clerc, C. and Lagabrielle, Y., 2014. Thermal control on the modes of crustal thinning leading to mantle exhumation. Insights from the Cretaceous Pyrenean hot paleomargins.: Tectonics,, p. 2013TC003471, doi: 10.1002/2013TC003471.

Clerc, C., Lagabrielle, Y., Neumaier, M., Reynaud, J.-Y. and Saint-Blanquat, M., 2012. Exhumation of subcontinental mantle rocks: evidence from ultramafic-bearing clastic deposits nearby the Lherz peridotite body, French Pyrenees: Bulletin de la Societe Geologique de France, 183, p. 443-459, doi: 10.2113/gssgfbull.183.5.443.

Clerc, C., Lahfid, A., Monié, P., Lagabrielle, Y., Chopin, C., Poujol, M., Boulvais, P., Ringenbach, J.-C., Masini, E. and de St Blanquat, M., 2015. High-temperature 
metamorphism during extreme thinning of the continental crust: a reappraisal of the north Pyrenean paleo-passive margin: Solid Earth, 6, p. 643-668, doi: doi:10.5194/se-6-643-2015.

Combes, P.-J., 1969. Recherches sur la genèse des bauxites dans le Nord-Est de l'Espagne, le Languedoc et l'Ariège (France): Montpellier, France.

Combes, P.-J. and Peybernès, B., 1989. Tectonique albienne dans les gisments de bauxites des Pyrénées ariègeoises (France) en relation avec l'évolution géodynamique de la marge passive européenne: C. R. Acad. Sci. Paris, serie II, 308, p. 953-959.

Contrucci, I., Matias, L., Moulin, M., Géli, L., Klingelhofer, F., Nouzé, H., Aslanian, D., Olivet, J.L., Réhault, J.-P. and Sibuet, J.-C., 2004. Deep structure of the West African continental margin (Congo, Zaïre, Angola), between $5^{\circ} \mathrm{S}$ and $8^{\circ} \mathrm{S}$, from reflection/refraction seismics and gravity data: Geophysical Journal International, 158, p. 529-553, doi: 10.1111/j.1365-246X.2004.02303.x.

Corre, B., Lagabrielle, Y., Labaume, P., Fourcade, S., Clerc, C. and Ballèvre, M., 2015. Deformation associated to mantle exhumation in a distal, hot passive margin environment: example of the Saraillé Massif (Chaînons Béarnais, North Pyrenean Zone).: Comptes Rendus Geosciences.

Costa, S. and Maluski, H., 1988. Use of the 40Ar-39Ar stepwise heating method for dating mylonite zones: An example from the St. Barthélémy massif (Northern Pyrenees, France): Chemical Geology: Isotope Geoscience section, 72, p. 127-144, doi: 10.1016/0168-9622(88)90061-9.

Crochet, B., Villatte, J., Tambareau, Y., Bilotte, M., Bousquet, J.-P., Kuhfuss, A., Bouillin, J.P., Gelard, J.-P., Bessière, G. and Paris, J.-P., 1989. Carte géol. France (1/50 000), feuille Quillan (1077):

Dauteuil, O. and Ricou, L.E., 1989. Une circulation de fluides de haute température à l'origine du métamorphisme crétacé nord-Pyrénéen.: Geodin. Acta, 3, p. 237-250.

Debroas, E.-J., 1978. Evolution de la fosse du flysch ardoisier de l'albien supérieur au Sénonien inférieur (zone interne métamorphique des Pyrénées navarrolangudociennes): Bull. Soc. Géol. Fr., 20, p. 639-648.

Debroas, E.-J., 1987. Le flysch à fucoïdes d'Uchentein témoin d'un escarpement turonosénonien inférieur de la paléofaille nord pyrénéenne, Pyrénées Centrales, France.: Strata,, p. 77-93.

Debroas, E.-J., 1990. Le flysch noir albo-cenomanien témoin de la structuration albienne à sénonienne de la Zone nord-pyrénéenne en Bigorre (Hautes-Pyrénées, France): Bulletin de la société Géologique de france, 8, p. 273-285.

Debroas, E.-J., 1976. Sédimentogenèse et position structurale des flyschs crétacés du versant nord des Pyrénées centrales: Bull. Bur. Rech. Géol. Min., I, p. 305-320. 
Demange, M. and Pascal, M.-L., 1979. Structure du massif nord-Pyreneen de Salvezines (Aude).: Comptes Rendus de l'Académie des Sciences, 289, p. 711-714.

Destombes, J.P., 1946. L'anticlinal de la Fontaine Salée à Sougraigne (Aude): Bull. Soc. Géol. Fr., 5, p. 371-384.

Diaz, J., Gallart, J., Ruiz, M., Pulgar, J.A., Lopez-Fernandez, C. and Gonzalez-Cortina, J.M., 2006. Probing seismic anisotropy in North Iberia from shear wave splitting: Physics of the Earth and Planetary Interiors, 158, p. 210-225, doi: doi:10.1016/j.pepi.2005.12.011.

Durand-Delga, M., 1965. Au sujet de la phase anté-cénomanienne à l'Est de Quillan: $C . R$. somm. Soc. geol. Fr., 2, p. 61-62.

Durand-Delga, M., 1964. Remarques sur la stratigraphie et la structure du Mésozoïque situé entre Estagel et Perpignan (Pyrénées-Orientales): Comptes Rendus de l'Académie des Sciences, Paris, 259, p. 837-840.

Ellenberger, F. and Berger, G., 1985. Carte géol. France (1/50 000), feuille Capendu (1060): Bureau de recherches géologiques et minières.

Fabriès, J., J.-P. Lorand, et J.-L. Bodinier. 1998. « Petrogenetic evolution of orogenic lherzolite massifs in the central and western Pyrenees ». Tectonophysics 292 (12): 145- 67. doi:10.1016/S0040-1951(98)00055-9.

Fabriès, J., J.-P. Lorand, J.-L. Bodinier, et C. Dupuy. 1991. « Evolution of the Upper Mantle beneath the Pyrenees: Evidence from Orogenic Spinel Lherzolite Massifs ». Journal of Petrology Special_Volume (2): 55- 76. doi:10.1093/petrology/Special_Volume.2.55.

Fallourd, S., Poujol, M., Boulvais, P., Paquette, J.-L., Blanquat, M. de S. and Rémy, P., 2014. In situ LA-ICP-MS U-Pb titanite dating of $\mathrm{Na}-\mathrm{Ca}$ metasomatism in orogenic belts: the North Pyrenean example: International Journal of Earth Sciences, 103, p. 667682, doi: 10.1007/s00531-013-0978-1.

Fonteilles, M., Leblanc, D., Clauzon, G., Vaudin, J.L. and Berger, G.M., 1993. Carte géol. France (1/50 000), feuille Rivesaltes (1090):

Golberg, J.-M., H. Maluski, et A.-F. Leyreloup. 1986. « Petrological and age relationship between emplacement of magmatic breccia, alkaline magmatism, and static metamorphism in the North Pyrenean Zone ». Tectonophysics 129 (1-4): 275- 90. doi:10.1016/0040-1951(86)90256-8.

Golberg, J.-M., 1987. Le métamorphisme mésozö̈que dans la partie orientale des Pyrénées: relation avec l'évolution de la chaîne au Crétacé.: Université des Sciences et Techniques du Languedoc, Montpellier.

Golberg, J.-M., et H. Maluski. 1988. « Données nouvelles et mise au point sur l'âge du métamorphisme pyrénéen. » C. R. Acad. Sci. Paris 306: 429-35. 
Golberg, J.-M. and Leyreloup, A.-F., 1990. High temperature-low pressure Cretaceous metamorphism related to crustal thinning (Eastern North Pyrenean Zone, France): Contributions to Mineralogy and Petrology, 104, p. 194-207.

Golberg, J.-M., Maluski, H. and Leyreloup, A.-F., 1986. Petrological and age relationship between emplacement of magmatic breccia, alkaline magmatism, and static metamorphism in the North Pyrenean Zone: Tectonophysics, 129, p. 275-290, doi: 10.1016/0040-1951(86)90256-8.

Goujou, J.C., Golberg, J.-M. and Leyreloup, A.-F., 1988. Réactions de décarbonation dans les roches calcaréo-pélitiques de la Ballongue (zone nord pyrénéenne. 1.

Formation de biotite et de plagioclase.: C. R. Acad. Sci. Paris, serie II, 307, p. 39-44.

Handy, M.R., M. Schmid, S., Bousquet, R., Kissling, E. and Bernoulli, D., 2010. Reconciling plate-tectonic reconstructions of Alpine Tethys with the geological-geophysical record of spreading and subduction in the Alps: Earth-Science Reviews, 102, p. 121-158, doi: 10.1016/j.earscirev.2010.06.002.

Harris, L.B., Koyi, H.A. and Fossen, H., 2002. Mechanisms for folding of high-grade rocks in extensional tectonic settings: Earth-Science Reviews, 59, p. 163-210, doi: doi:10.1016/S0012-8252(02)00074-0.

Huismans, Ritske, et Christopher Beaumont. 2011. « Depth-dependent extension, twostage breakup and cratonic underplating at rifted margins ». Nature 473 (7345): 74- 78. doi:10.1038/nature09988.

Huismans, Ritske S., et Christopher Beaumont. 2014. «Rifted continental margins: The case for depth-dependent extension ». Earth and Planetary Science Letters 407: 148-62. doi:10.1016/j.epsl.2014.09.032.

Jammes, S., Manatschal, G., Lavier, L.L. and Masini, E., 2009. Tectonosedimentary evolution related to extreme crustal thinning ahead of a propagating ocean: Example of the western Pyrenees: Tectonics, 28, doi: 10.1029/2008TC002406.

Jammes, S., Tiberi, C. and Manatschal, G., 2010. 3D architecture of a complex transcurrent rift system: The example of the Bay of Biscay-Western Pyrenees: Tectonophysics, 489, p. 210-226, doi: 10.1016/j.tecto.2010.04.023.

Lagabrielle, Y. and Bodinier, J.-L., 2008. Submarine reworking of exhumed subcontinental mantle rocks: field evidence from the Lherz peridotites, French Pyrenees: Terra Nova, 20, p. 11-21, doi: 10.1111/j.1365-3121.2007.00781.x.

Lagabrielle, Y., Clerc, C., Vauchez, A., Lahfid, A., Labaume, P., Azambre, B., Fourcade, S. and Dautria, J.-M., 2015. Very high geothermal gradient during mantle exhumation recorded in mylonitic marbles and carbonate breccias from a Mesozoic Pyrenean paleomargin (Lherz, North Pyrenean Zone, France): Comptes Rendus Géosciences.

Lagabrielle, Y., Labaume, P. and St Blanquat, M., 2010. Mantle exhumation, crustal denudation, and gravity tectonics during Cretaceous rifting in the Pyrenean 
realm (SW Europe): Insights from the geological setting of the lherzolite bodies: Tectonics, 29, p. 1-26, doi: 10.1029/2009TC002588.

Lagabrielle Y., Clerc C., Vauchez A., Lahfid A., Labaume P., Azambre B., Fourcade F., Dautria JM. (2016). Very high geothermal gradient during mantle exhumation recorded in mylonitic marbles and carbonate breccias from a Mesozoic Pyrenean paleo-margin (Lherz area, North Pyrenean Zone, France). Comptes Rendus Geoscience, Special Issue, The Pyrénées : M. Godard, Y. Lagabrielle, M. de Saint Blanquat, eds.

Lago, M., Arranz, E., Pocoví, A., Galé, C. and Gil-Imaz, A., 2004. Permian magmatism and basin dynamics in the southern Pyrenees: a record of the transition from late Variscan transtension to early Alpine extension: Geological Society, London, Special Publications, 223, p. 439-464, doi: 10.1144/GSL.SP.2004.223.01.19.

Légier, C., Tempier, C. and Vauchez, A., 1987. Tectoniques tangentielle ductile synmétamorphe d'âge Crétacé supérieur dans la couverture du massif de l'Agly (zone Nord-pyrénéenne orientale).: Comptes Rendus de l'Académie des Sciences, Paris, 305, p. 907-911.

Le Pichon, X., Bonnin, J. and Sibuet, J.-C., 1970. La faille nord-Pyrénéenne: Faille transformante liée à l'ouverture du Golfe de Gascogne: Comptes Rendus de l'Académie des Sciences, 271, p. 1941-1944.

Manatschal, G., 2004. New models for evolution of magma-poor rifted margins based on a review of data and concepts from West Iberia and the Alps: International Journal of Earth Sciences, 93, p. 432-466, doi: 10.1007/s00531-004-0394-7.

Masini, E., Manatschal, G., Tugend, J., Mohn, G. and Flament, J.-M., 2014. The tectonosedimentary evolution of a hyper-extended rift basin: the example of the ArzacqMauléon rift system (Western Pyrenees, SW France): International Journal of Earth Sciences, 103, p. 1-28, doi: 10.1007/s00531-014-1023-8.

Mattauer, M., 1968. Les traits structuraux essentiels de la chaîne des Pyrénées.: Revue Géogr. phys. Géol. dyn., 10, p. 3-12.

Mattauer, M. and Henry, J., 1974. Pyrenees: Geological Society, London, Special Publications, 4, p. 3 -21, doi: 10.1144/GSL.SP.2005.004.01.01.

Mattauer, M. and Proust, F., 1964. Sur l'allure de la discordance anté-cénomanienne dans le bassin de Quillan (partie orientale des Pyrénées): C.R. somm. S.G.F., p. 340-342.

McClay, K., Munoz, J.-A., Garcia-Senz, J., 2004. Extensional salt tectonics in a contractional orogen: A newlyidentified tectonic event in the Spanish Pyrenees. Geology, 9, 737-740.

Montigny, R., Azambre, B., Rossy, M. and Thuizat, R., 1986. K-Ar Study of cretaceous magmatism and metamorphism in the pyrenees: Age and length of rotation of the Iiberian Peninsula: Tectonophysics, 129, p. 257-273, doi: 10.1016/00401951(86)90255-6.

Moulin, M., Aslanian, D., Olivet, J.-L., Contrucci, I., Matias, L., Géli, L., Klingelhoefer, F., Nouzé, H., Réhault, J.-P. and Unternehr, P., 2005. Geological constraints on the 
evolution of the Angolan margin based on reflection and refraction seismic data (ZaïAngo project): Geophysical Journal International, 162, p. 793-810, doi: 10.1111/j.1365-246X.2005.02668.x.

Muñoz, J.A., 1992. Evolution of a continental collision belt: ECORS-Pyrenees crustal balanced cross-section. In: Thrust Tectonics K. McClay, London, p. 235-246.

Olivet, J.L., 1996. La cinématique de la plaque ibérique: Bull. Cent. Rech. Explor. Prod. ElfAquitaine, 20, p. 131-195.

Olivier, Ph, G. Gleizes, et J. L. Paquette. 2004. « Gneiss Domes and Granite Emplacement in an Obliquely Convergent Regime: New Interpretation of the Variscan Agly Massif (Eastern Pyrenees, France) ». Geological Society of America Special Papers 380 (janvier): 229- 42. doi:10.1130/0-8137-2380-9.229.

Osmundsen, P.T. and Ebbing, J., 2008. Styles of extension offshore mid-Norway and implications for mechanisms of crustal thinning at passive margins: Tectonics, 27, p. TC6016, doi: 10.1029/2007TC002242.

Ovtracht, A. and Lenguin, M., 1977. Carte géol. France (1/50 000), feuille Limoux (1059): BRGM.

Paquet, J. and Mansy, J.-L., 1991. La structure de l'Est des Pyrénées (transversales du massif de l'Agly): un exemple d'amincissement crustal.: Comptes Rendus de l'Académie des Sciences - Serie II,, p. 913-919.

Passchier, C.W., 1984. Mylonite-Dominated Footwall Geometry in a Shear Zone, Central Pyrenees: Geological Magazine, 121, p. 429-436, doi: $10.1017 / \mathrm{S} 0016756800029964$.

Peybernès, B., 1976. Le jurassique et le Crétacé inférieur des Pyrénées francoespagnoles antre la Garonne et la Méditerranée. [Thèse]: Univ. Toulouse, 459 p.

Poujol, M., Boulvais, P. and Kosler, J., 2010. Regional-scale Cretaceous albitization in the Pyrenees: evidence from in situ U-Th-Pb dating of monazite, titanite and zircon: Journal of the Geological Society, 167, p. 751-767, doi: 10.1144/0016-76492009144.

Ravier, J., 1959. Le métamorphisme des terrains secondaires des Pyrénées: Mem. Soc. Geol. Fr., 86, p. 1-250.

Reston, T.J., 1988. Evidence for shear zones in the lower crust offshore Britain: Tectonics, 7, p. 929-945, doi: 10.1029/TC007i005p00929.

Rosenbaum, G., Lister, G.S. and Duboz, C., 2002. Relative motions of Africa, Iberia and Europe during Alpine orogeny: Tectonophysics, 359, p. 117-129, doi: doi:10.1016/S0040-1951(02)00442-0.

Roure, F., Choukroune, P., Berastegui, X., Munoz, J.A., Vilien, A., Matheron, P., Bareyt, M., Seguret, M., Camara, P. and Deramond, J., 1989. Ecors deep seismic data and 
balanced cross sections: Geometric constraints on the evolution of the Pyrenees: Tectonics, 8, p. 41-50.

Schärer, U., de Parseval, P., Polvé, M. and St Blanquat, M., 1999. Formation of the Trimouns talc-chlorite deposit (Pyrenees) from persistent hydrothermal activity between 112 and 97 Ma: Terra Nova, 11, p. 30-37, doi: 10.1046/j.13653121.1999.00224.x.

Sibuet, J.-C., 2004. Pyrenean orogeny and plate kinematics: Journal of Geophysical Research, 109, doi: 10.1029/2003JB002514.

Souquet, P., Debroas, E.-J., Boirie, J.-M., Pons, P., Fixari, G., Dol, J., Thieuloy, J.-P., Bonnemaison, M., Manivit, H. and Peybernès, B., 1985. Le groupe du Flysch noir (albo-cénomanien) dans les Pyrénées: Bull. centres de Rech. Exlpo.-Prod. ElfAquitaine, Pau, 9, p. 183-252.

Srivastava, S.P., Sibuet, J.-C., Cande, S., Roest, W.R. and Reid, I.D., 2000. Magnetic evidence for slow seafloor spreading during the formation of the Newfoundland and Iberian margins: Earth and Planetary Science Letters, 182, p. 61-76, doi: doi:10.1016/S0012-821X(00)00231-4.

Stampfli, G.M., Borel, G.D., Marchant, R. and Mosar, J., 2002. Western Alps geological constraints on western Tethyan reconstructions: Journal of the Virtual Explorer, 08, doi: 10.3809/jvirtex.2002.00057.

St Blanquat, M., Bajolet, F., Clerc, C., Grand'Homme, A., Proietti, A., Boutin, A., Lagabrielle, Y. and Labaume, P., 2015. Cretaceous mantle exhumation in the Central Pyrenees: New constraints from the lherzolites in eastern Ariege (North Pyrenean Zone, France): Comptes Rendus Geosciences.

St Blanquat, M., Lardeaux, J.M. and Brunel, M., 1990. Petrological arguments for hightemperature extensional deformation in the Pyrenean Variscan crust (Saint Barthélémy Massif, Ariège, France): Tectonophysics, 177, p. 245-262, doi: 10.1016/0040-1951(90)90284-F.

Teixell, A., 1998. Crustal structure and orogenic material budget in the west central Pyrenees: Tectonics, 17, p. 395-406, doi: 199810.1029/98TC00561.

Ternet, Y., Colchen, M., Debroas, E.-J., Azambre, B., Debon, F., Bouchez, J.-L., Gleizes, G., Leblanc, D., Bakalowicz, M., Jauzion, G., Mangin, A. and Soulé, J.-C., 1997. Notice explicative, Carte géol. France (1/50 000), feuille Aulus les Bains (1086): BRGM, Orléans.

Tugend, J., Manatschal, G., Kusznir, N.J., Masini, E., Mohn, G. and Thinon, I., 2014. Formation and deformation of hyperextended rift systems: Insights from rift domain mapping in the Bay of Biscay-Pyrenees: Tectonics, 33, p. 1239-1276, doi: 10.1002/2014TC003529.

Unternehr, P., Péron-Pinvidic, G., Manatschal, G. and Sutra, E., 2010. Hyper-extended crust in the South Atlantic: in search of a model: Petroleum Geoscience, 16, p. 207-215, doi: 10.1144/1354-079309-904. 
Vacherat, A., Mouthereau, F., Pik, R., Bernet, M., Gautheron, C., Masini, E., Le Pourhiet, L., Tibari, B. and Lahfid, A., 2014. Thermal imprint of rift-related processes in orogens as recorded in the Pyrenees: Earth and Planetary Science Letters, 408, p. 296-306, doi: 10.1016/j.epsl.2014.10.014.

Vauchez, A., Clerc, C., Bestani, L., Lagabrielle, Y., Chauvet, A., Lahfid, A. and Mainprice, D., 2013. Preorogenic exhumation of the North Pyrenean Agly massif (Eastern Pyrenees-France): Tectonics, 32, p. 95-106, doi: 10.1002/tect.20015.

Vergés, J., Millàn, H., Munoz, J.A., Marzo, M., Cirés, J., Den Bezemer, T., Zoetemeijer, R. and Cloething, S., 1995. Eastern Pyrenees and related foreland basins: pre-, syn- and post-collisional crustal-scale cross-sections: Marine and Petroleum Geology, 12, p. 903-915.

Vielzeuf, D. and Kornprobst, J., 1984. Crustal splitting and the emplacement of Pyrenean lherzolites and granulites: Earth and Planetary Science Letters, 67, p. 87-96, doi: 10.1016/0012-821X(84)90041-4.

Vissers, R.L.M. and Meijer, P.T., 2012. Mesozoic rotation of Iberia: Subduction in the Pyrenees? Earth-Science Reviews, 110, p. 93-110, doi:

10.1016/j.earscirev.2011.11.001. 


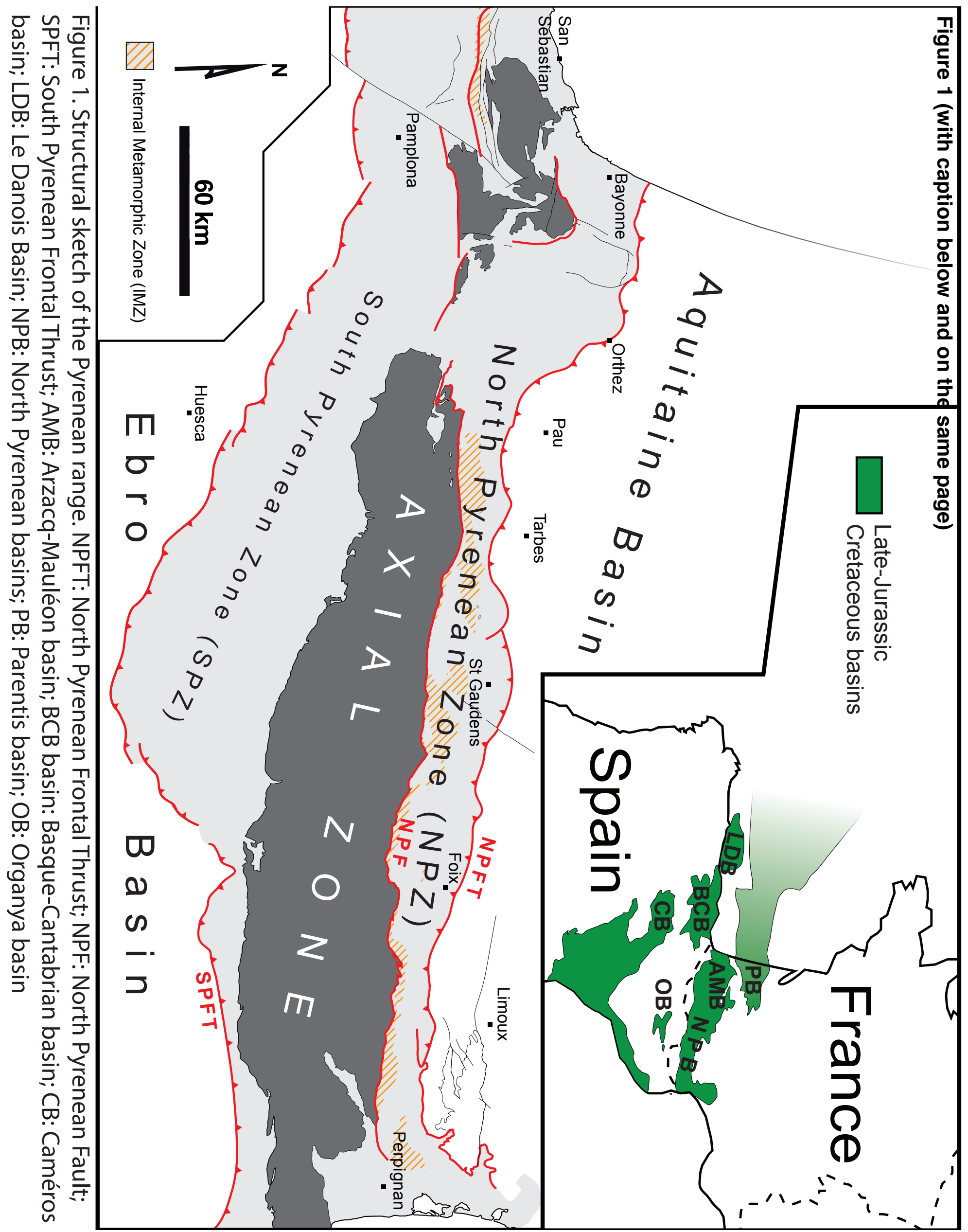




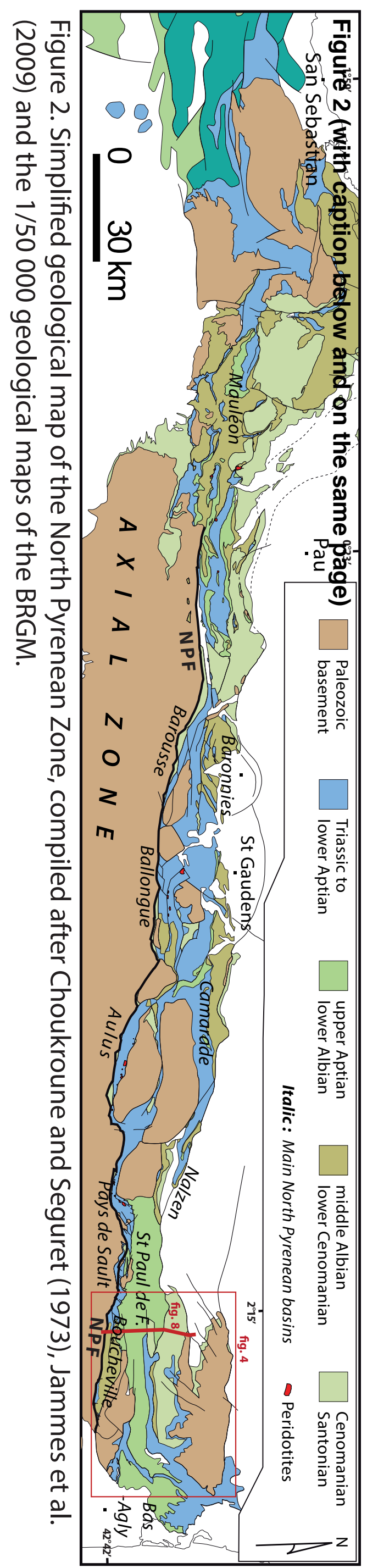


Bgure 3 (with caption below and on the same page) Axial zone massif

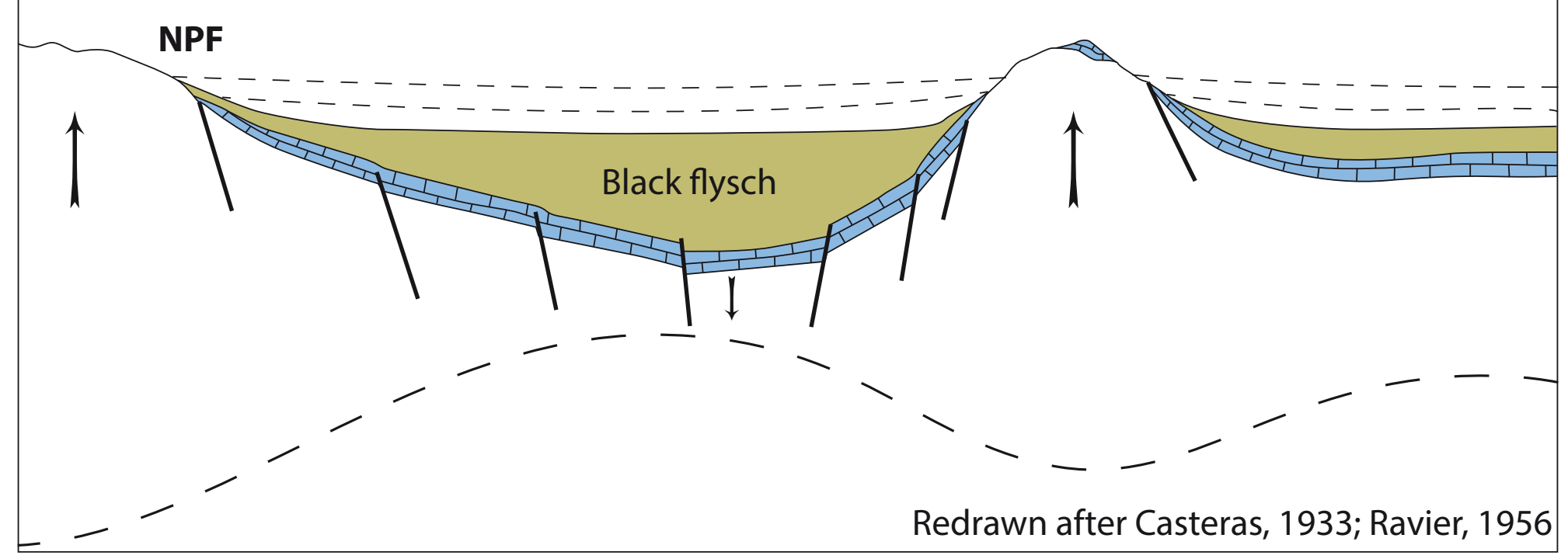

Figure 3: The North Pyrenean Zone as early represented by Casteras (1933) and Ravier (1959). The authors emphasized a rather smooth undulation of the Paleozoic basement controlling the deposition of the Albian-lower Cenomanian Black Flysch. Note that the mid-Cenomanian sediments about to be deposited will unconformably cover both the Black Flysch and pre-Albian strata. This geometry defines the "Pre-Cenomanian phase". 


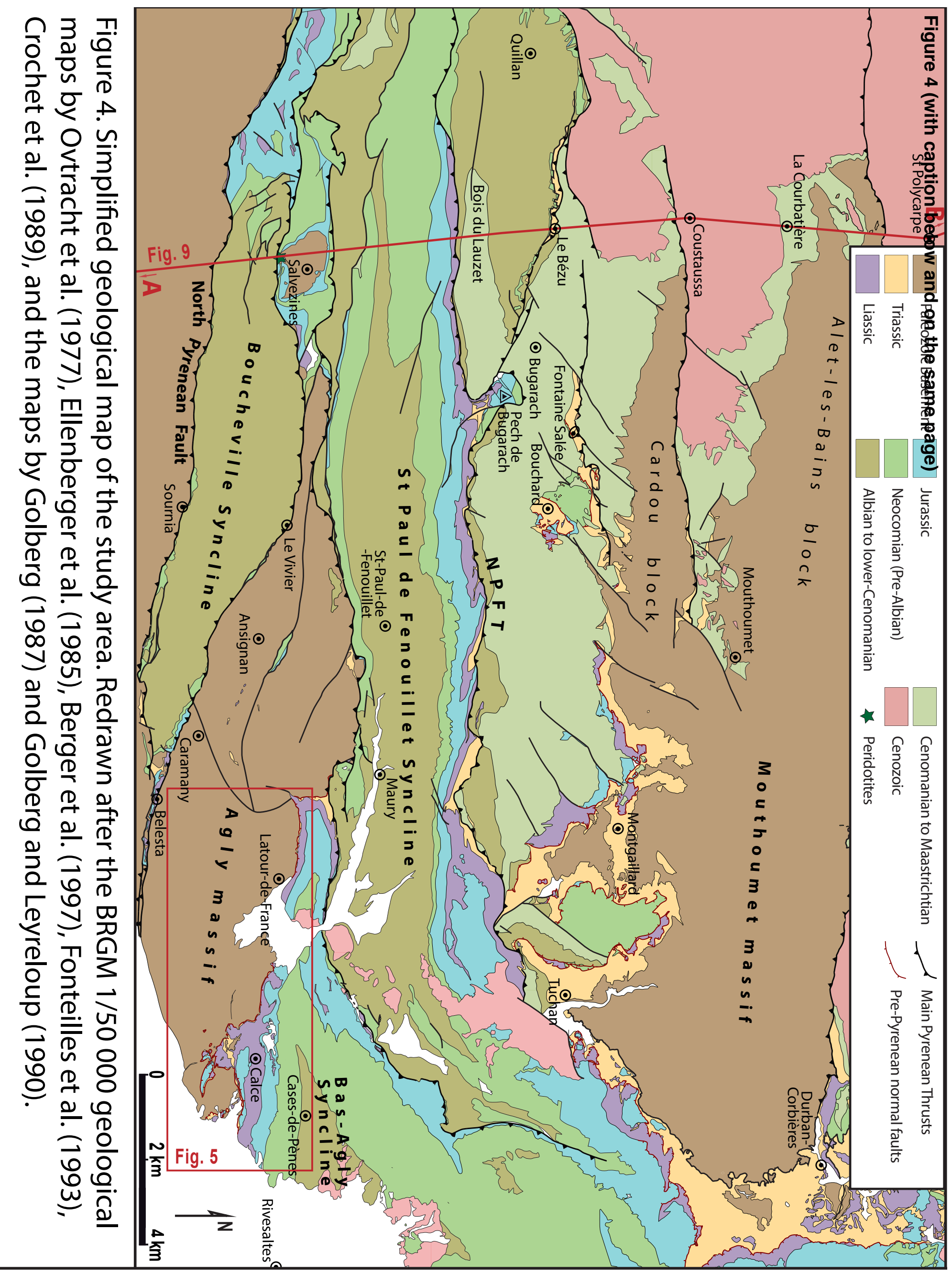



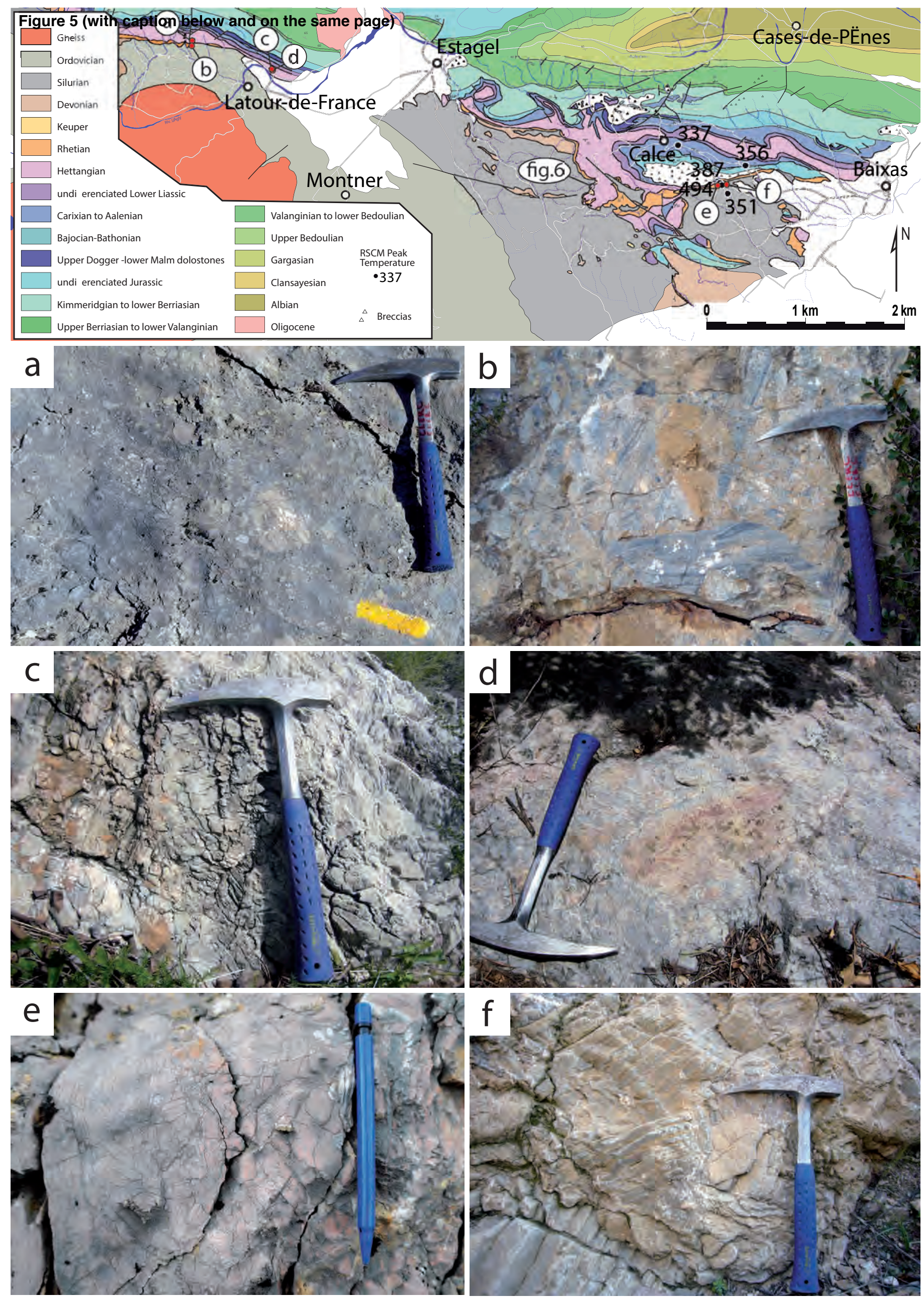

Figure 5. Up: Map of the northeastern termination of the Agly Paleozoic massif (location in figure 4) presenting evidences of basal truncations of the Mesozoic cover. The basal décollement is marked out by numerous monomictic tectonic breccias reworking ductily deformed Mesozoic metasediments (a to f). 


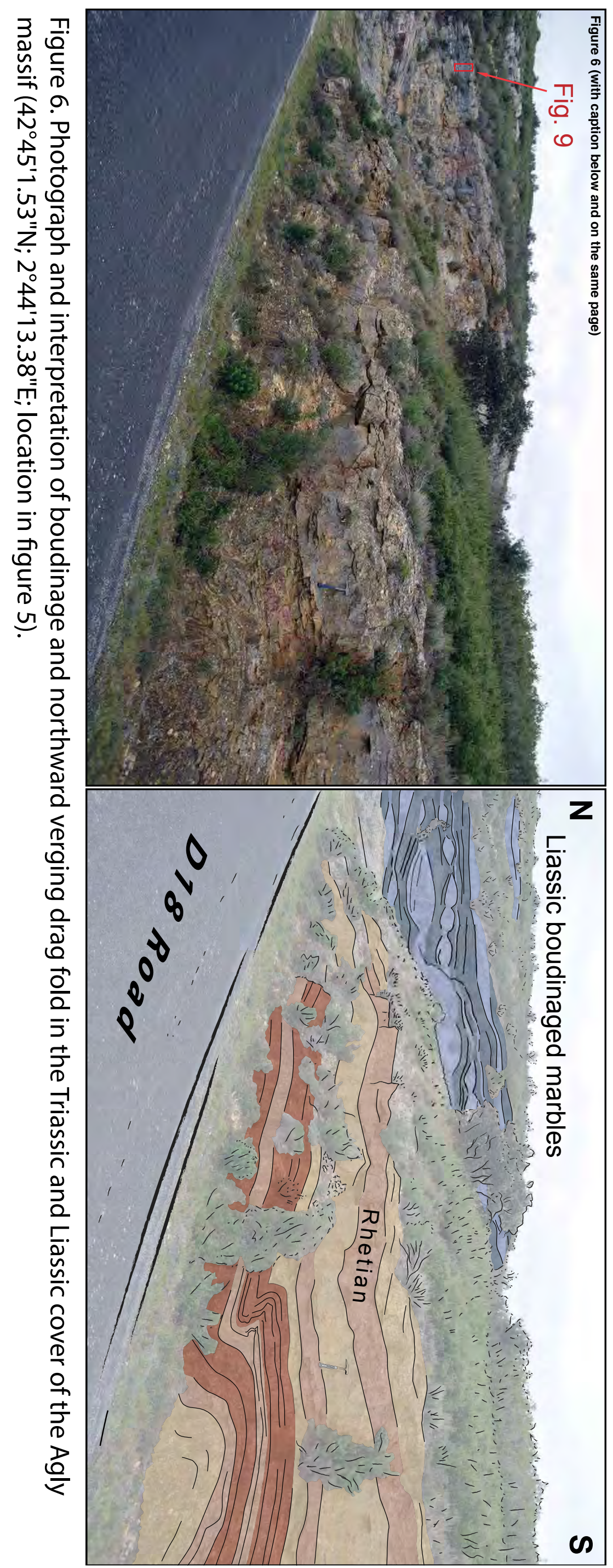




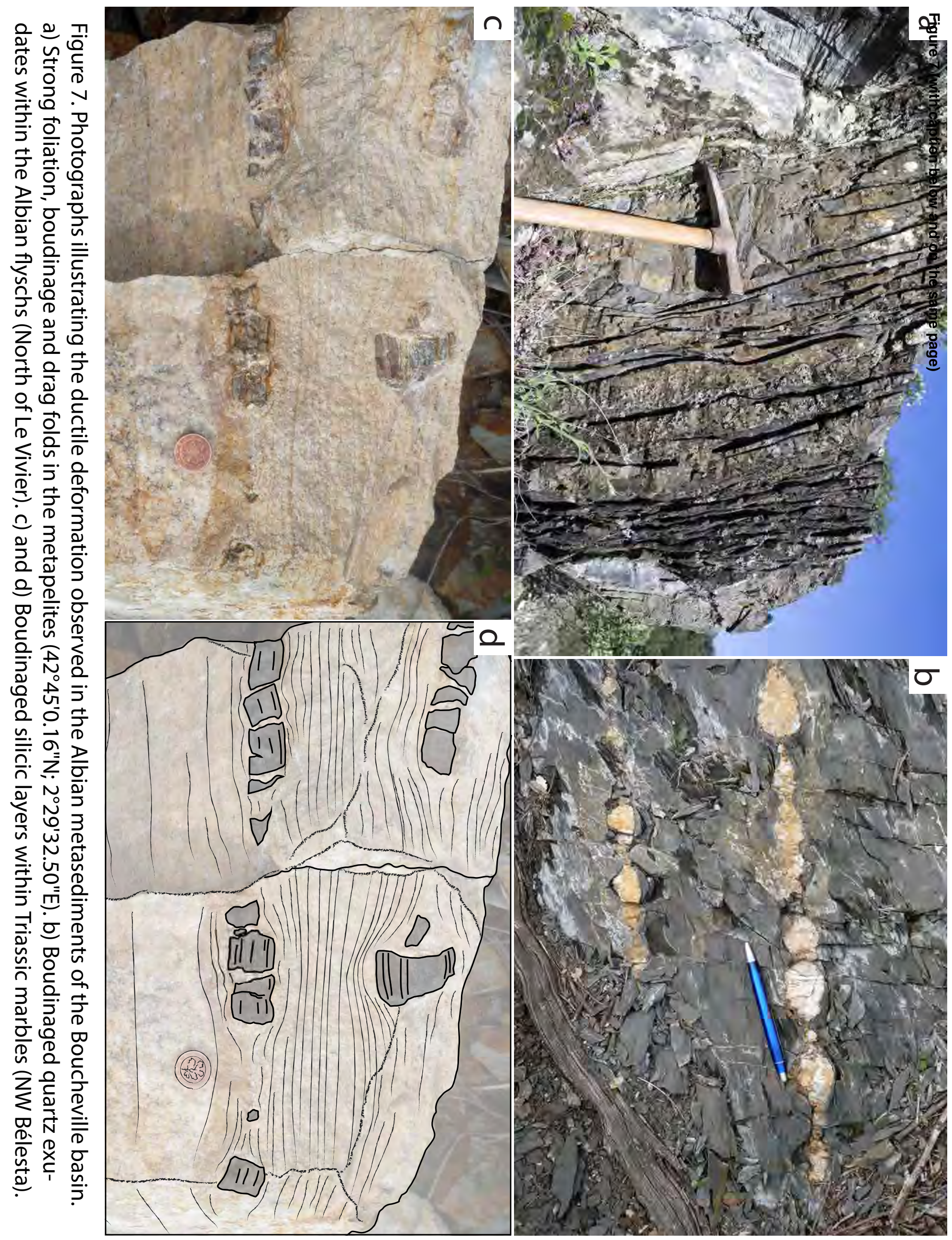




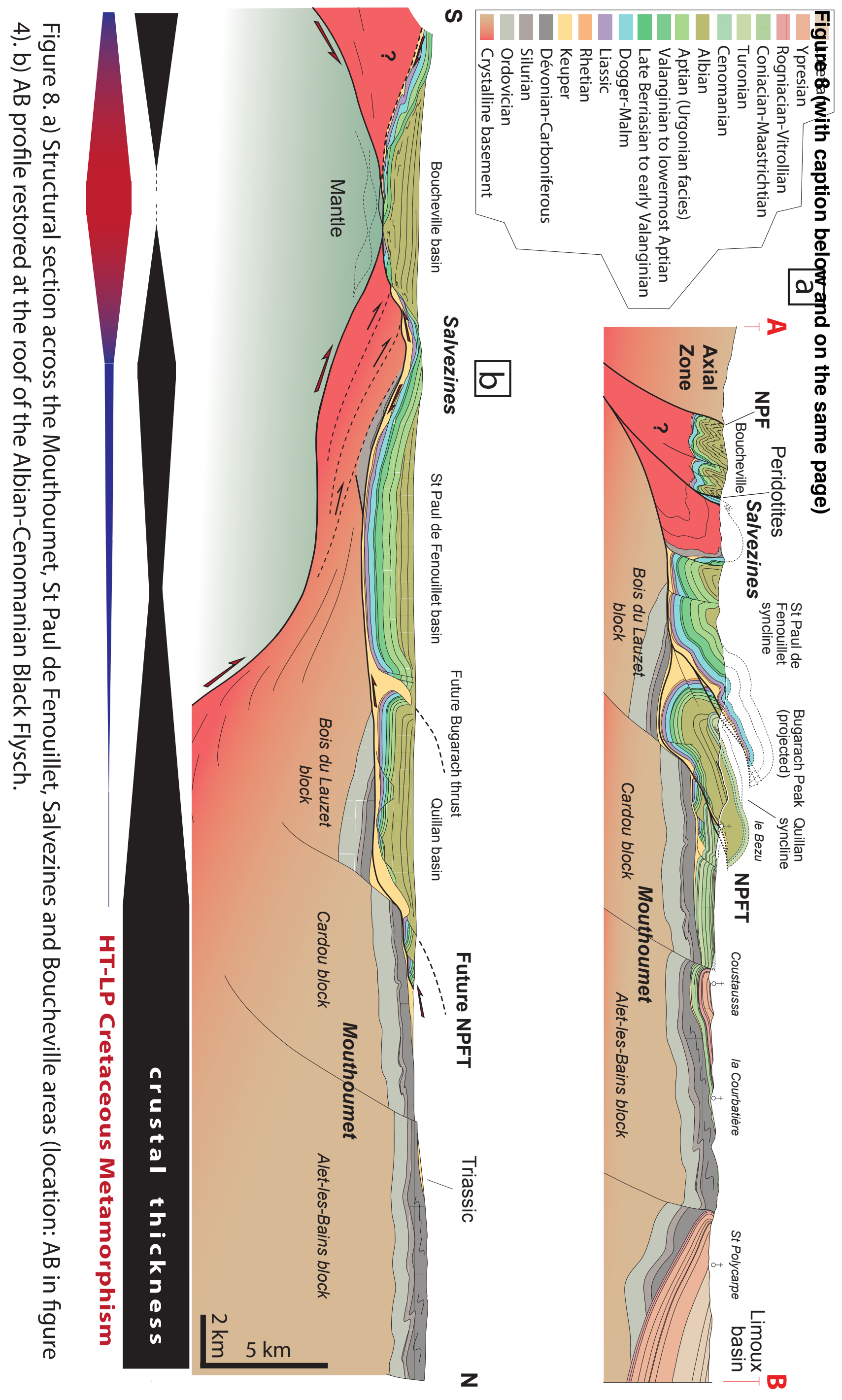




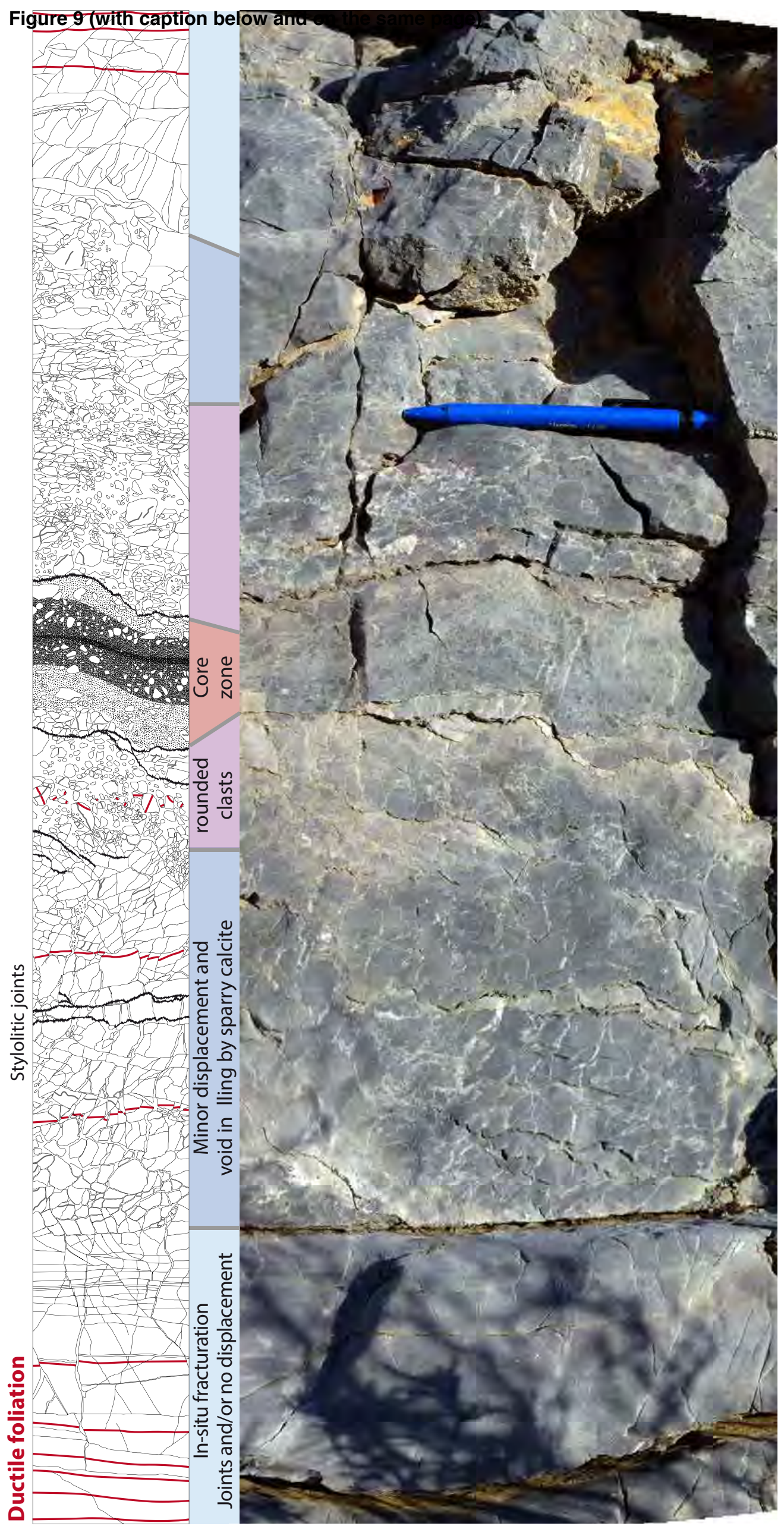

Figure 9. An example of brittle deformation affecting previously ductily deformed marbles in the Calce area $\left(42^{\circ} 45^{\prime} 1.53^{\prime \prime} \mathrm{N} ; 2^{\circ} 44^{\prime} 13.38\right.$ " $\mathrm{E}$; location in figure 6). The ductile foliation preserved on the upper and lower parts of the picture is progressively dismembered toward the center, with increasing clast displacement and clast size reduction. 


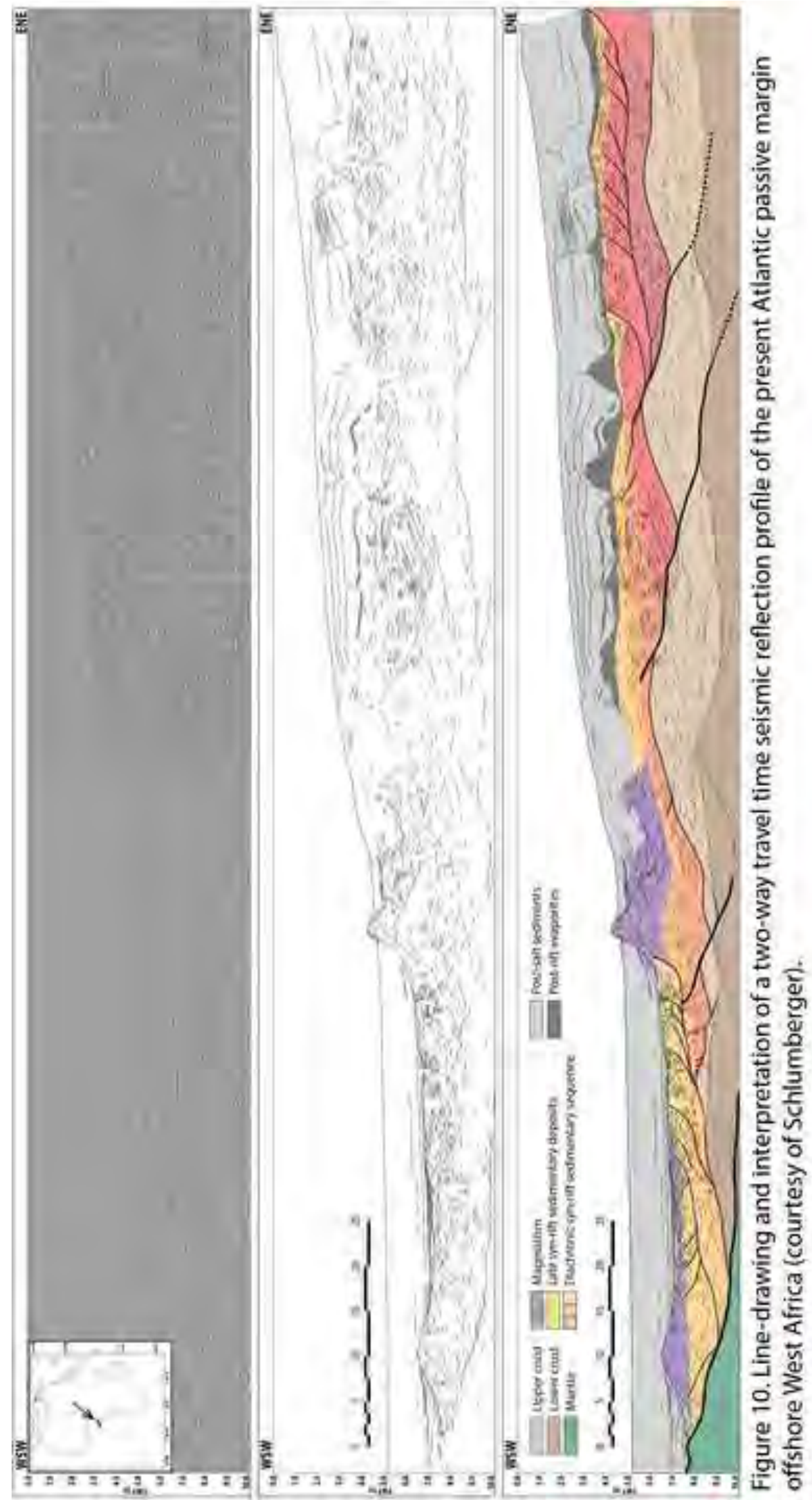



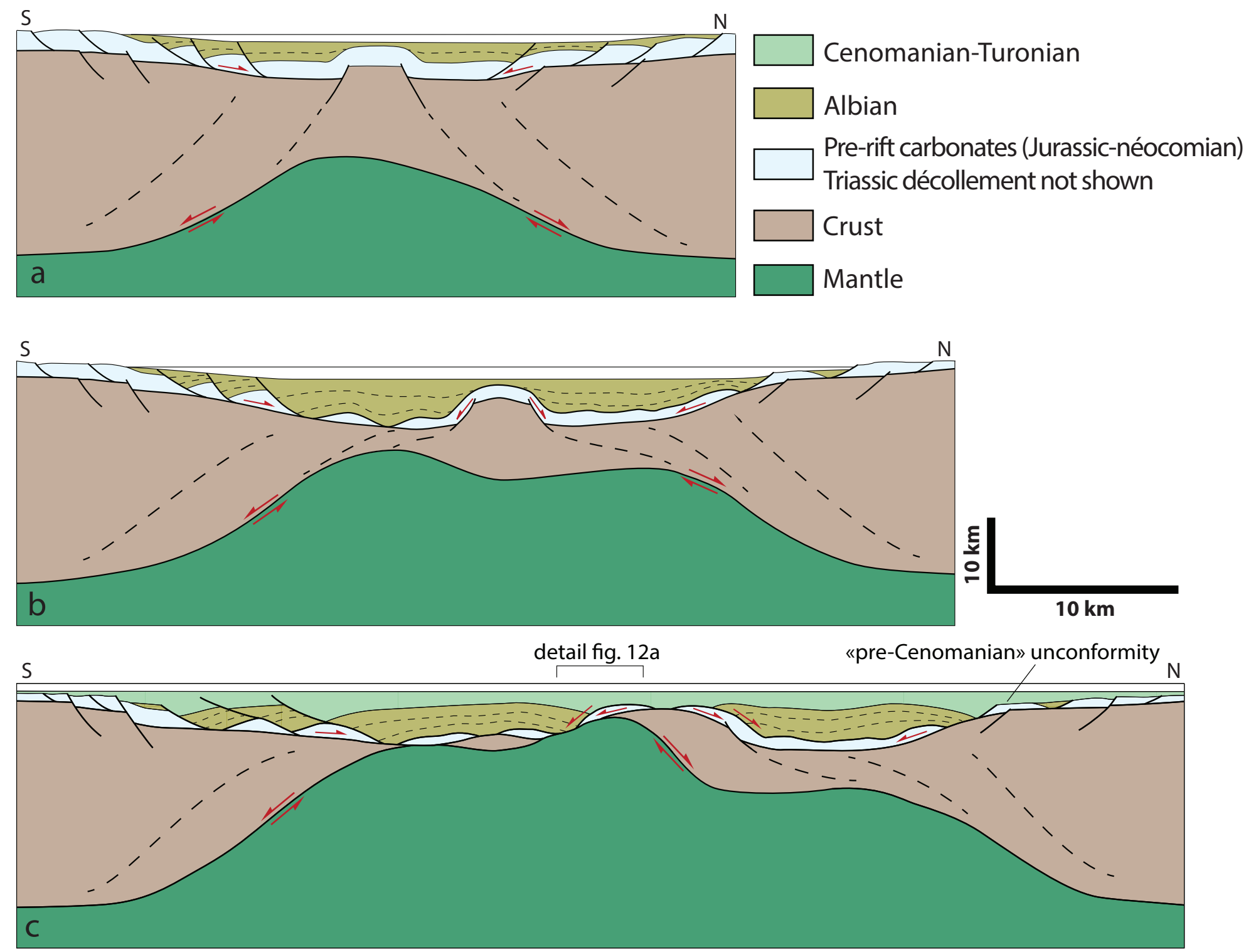

Figure 11. $a, b$ and c) Three steps conceptual model of margin evolution and related exhumation of metamorphic pre-rift Mesozoic sediments, based on features characteristic of the North-Eastern Pyrenean domain (step by step description in the text). 


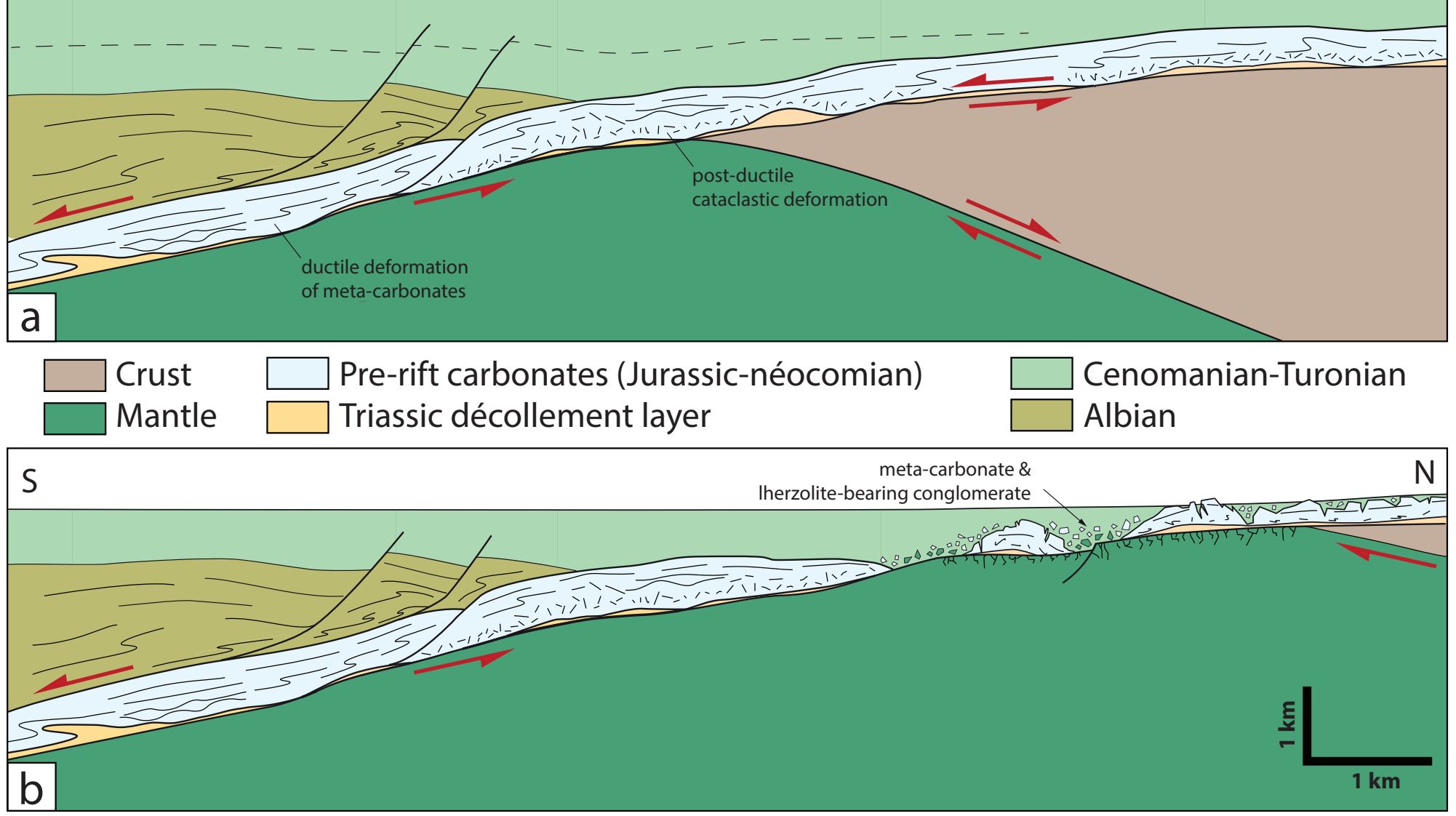

Figure 12. Two alternative details of the final stage of rifting and related exhumation. a) Zoom on figure 11 showing extraction of the pre-rift carbonates from below the syn-rift flysch and related transition from ductile to brittle deformation. b) Possible evolution where continuous extension leads to exhumation and sedimentary reworking of the subcontinental mantle as described in the Lherz and other areas (references in the text). 